This item was submitted to Loughborough's Research Repository by the author.

Items in Figshare are protected by copyright, with all rights reserved, unless otherwise indicated.

\title{
Nuclear weapons fallout 137Cs in temperate and tropical pine forest soils, 50 years post-deposition
}

\section{PLEASE CITE THE PUBLISHED VERSION}

https://doi.org/10.1016/j.scitotenv.2019.01.073

\section{PUBLISHER}

(C) Elsevier

VERSION

AM (Accepted Manuscript)

\section{PUBLISHER STATEMENT}

This paper was accepted for publication in the journal Science of the Total Environment and the definitive published version is available at https://doi.org/10.1016/j.scitotenv.2019.01.073.

LICENCE

CC BY-NC-ND 4.0

\section{REPOSITORY RECORD}

Itthipoonthanakorn, T., Sandie Dann, N.M.J. Crout, and G. Shaw. 2019. "Nuclear Weapons Fallout 137cs in Temperate and Tropical Pine Forest Soils, 50 Years Post-deposition”. figshare.

https://hdl.handle.net/2134/36601. 


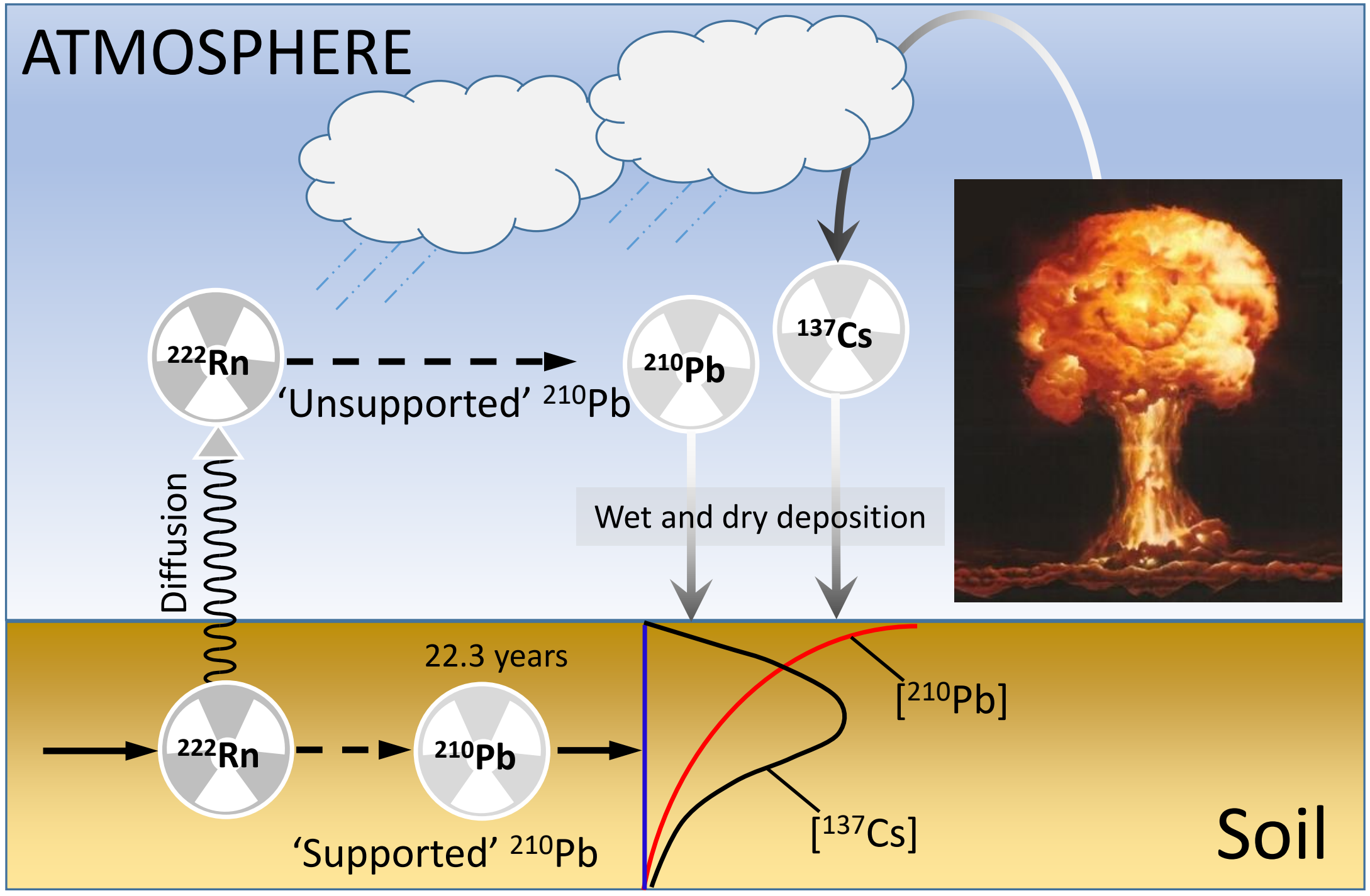




\section{Nuclear Weapons Fallout ${ }^{137} \mathrm{Cs}$ in Temperate and Tropical 2 Pine Forest Soils, 50 Years Post-Deposition}

3

$4 \quad{ }^{1 \S}$ Itthipoonthanakorn, T., ${ }^{2}$ S. E. Dann, ${ }^{1}$ N. M. J. Crout $\&{ }^{1 *}$ G. Shaw

5

6 1. School of Biosciences, University of Nottingham, Sutton Bonington, LE12 5RD, UK

7 2. Department of Chemistry, Loughborough University, Loughborough, LE11 3TU, UK

$8 \S$ Current address: Office of Atoms for Peace, Ministry of Science and Technology, 16 Vibhavadi 9 Rangsit Road, Bangkok 10900, Thailand

10

$11 *$ Correspondence to: george.shaw@nottingham.ac.uk 
13 Following nuclear releases to the environment, ${ }^{137} \mathrm{Cs}$ (half-life 30 years) is a long-term contaminant 14 of many ecosystems, including forests. We recently sampled soils under pine forests in temperate and tropical climates to test the hypothesis that migration of ${ }^{137} \mathrm{Cs}$, 50 years after nuclear weapons fallout, is coupled with organic matter (OM) accumulation in these soils. Depth profiles of ${ }^{137} \mathrm{Cs}$, naturally-occurring ${ }^{210} \mathrm{~Pb}$ and weapons-derived ${ }^{241} \mathrm{Am}$ were measured. After 50 years, migration of ${ }^{137} \mathrm{Cs}$ into the temperate and tropical soils is limited to half-depths of 7-8 cm and $2-3 \mathrm{~cm}$, respectively. At both locations, most ${ }^{137} \mathrm{Cs}$ is associated with $\mathrm{OM}$ that accumulated from the early to mid-1960s. Illite, which immobilises radiocaesium, was undetectable by X-ray diffraction in the layer of peak ${ }^{137} \mathrm{Cs}$ accumulation in the temperate forest soil, but apparent in the zone of peak concentration in the tropical soil. The data indicate that long-term (50 year) fate of ${ }^{137} \mathrm{Cs}$ in organicrich, temperate forest soil is coupled with OM accumulation; fixation of ${ }^{137} \mathrm{Cs}$ by illite is more important in the tropical forest soil where $\mathrm{OM}$ is rapidly decomposed. Models of long-term radiocaesium migration in forest soils should explicitly account for the role of $\mathrm{OM}$, especially when considering forests under contrasting climatic regimes. 
Caesium-137 is one of the most important radionuclides released to the environment by both reactor accidents and nuclear weapons; it often dominates the doses to humans and other organisms during the medium- and long-term after initial contamination (Smith and Beresford, 2005). The strong affinity of clay minerals, especially illite, for caesium means that soils with even a small clay content can be highly efficient in retarding the downwards migration of radiocaesium after deposition to the soil surface (Kirchner et al., 2009). Thus, in undisturbed mineral soils (eg. under pasture) radiocaesium may remain close to the soil surface many years after deposition (Bunzl et al., 1994). In mineral soils with a significant clay content, mixing by ploughing and bioturbation may be the dominant mechanism of radiocaesium migration through the upper soil profile. In organic soils which are deficient in clay minerals it is expected that radiocaesium migration will be faster than in mineral soils, since sorption and retention of caesium on organic matter is considerably lower than fixation by clays (Gil Garcia et al., 2009a). Furthermore, organic matter may actively reduce the efficiency with which clays can sequester radiocaesium (Dumat and Staunton, 1999). However, after the Chernobyl accident it was widely observed that radiocaesium that deposited on forest soils remained largely within the surface organic horizons at least up to 10 years after deposition (Ivanov et al., 1997) suggesting a significant potential for the retention of radiocaesium by organic matter in the upper portions of forest soils.

Numerous studies have examined radiocaesium migration in different soil types over varying time scales. In undisturbed organic-rich soil in Sweden in 1994-1998, Isaksson et al. (2001) found relaxation depths ${ }^{1}$ for ${ }^{137} \mathrm{Cs}$ of 0.7 to $1.6 \mathrm{~cm}$, indicating superficial distribution even of weapons fallout ${ }^{137} \mathrm{Cs}$ that peaked in the mid-1960s. Almgren and Isaksson (2006) measured median activity concentrations ('half-depths') at $8.9 \mathrm{~cm}$ for weapons-derived ${ }^{137} \mathrm{Cs}$ and $4.4 \mathrm{~cm}$ depth for Chernobyl ${ }^{137} \mathrm{Cs}$ in grassland in 2003. These distributions were quantified using a convection-diffusion model which assumes the vertical distribution of radiocaesium is determined purely by physical processes. Schimmack and Marquez (2006) used a convection-diffusion model to analyse radiocaesium migration in a grassland soil during a period of 15 years after the Chernobyl accident. They found that the fitted migration parameters (convective velocity and dispersion coefficient) were so timedependent that long-term predictions of caesium migration using this type of model were not realistic. In a meta-analysis of 99 soil profiles Jagercikova et al. (2015) concluded that the evolution of depth profiles of ${ }^{137} \mathrm{Cs}$ is "a complex result of the variations in soil processes affecting the diffusion and convection transport and resulting in contrasted temporal evolutions".

\footnotetext{
${ }^{1}$ Defined as the depth at which the surface activity concentration is reduced to 1 /e (approximately $37 \%$ ) assuming an exponentially declining distribution of activity concentration with depth.
} 
Interestingly, Jagercikova et al. (2015) omitted from their analysis four soil profiles in which more than $30 \%$ of the ${ }^{137} \mathrm{Cs}$ inventory within the soil was held in organic horizons, presumably because these distributions were not straightforwardly explained by convection-diffusion theory. In highly organic soils, mechanisms other than classical solute transport of radiocaesium, modified by sorption to clays, may operate. Rosen et al. (2009) found median depths of 10.7 and $15 \mathrm{~cm}$ for Chernobyl-derived ${ }^{137}$ Cs in open and pine-covered bog ecosystems in Sweden from $2004-2007$ in which the clay content was "extremely low or non-existent". They observed that upwards migration of ${ }^{137} \mathrm{Cs}$ had occurred in the open bog due to uptake and upward transport in Sphagnum plants, thus emphasising that biological as well as physical processes can contribute to the observed migration of radiocaesium. Dorr and Munnich (1989) established a link between organic matter and radiocaesium migration in forest soils in southern Germany. They determined that naturallyoccurring 'unsupported' ${ }^{210} \mathrm{~Pb}$ deposited from the atmosphere migrated with an identical velocity as the accumulating organic matter; they also noted that migration rates of both ${ }^{210} \mathrm{~Pb}$ and ${ }^{137} \mathrm{Cs}$ were unaffected by the soil mineral texture that, in their study, included sandy, loamy and clayey soils. This implies that, in forest soils with high annual organic matter inputs, the influence of organic matter on ${ }^{210} \mathrm{~Pb}$ and ${ }^{137} \mathrm{Cs}$ migration can override the tendency for these radionuclides to be sorbed to mineral components of the soil.

The temporal evolution of radiocaesium in an individual soil profile is key to the radiation dose received by organisms (including man) above the surface of the soil and also to its availability for root uptake by vegetation. In the case of forests, the long-term dynamics of contamination of trees and all associated products (edible and non-edible) are thus strongly dependent on the migration of radiocaesium through the soil profile. After major nuclear releases such as the Chernobyl and Fukushima accidents, management of contaminated forests requires accurate forecasting of the long term fate of radiocaesium, as well as careful consideration of remediation options such as removal and processing of contaminated litter from the forest floor (Hashimoto et al., 2012). Modelling of the fate of radiocaesium in Fukushima's forests has suggested that contamination of the mineral soil beneath the litter layer would peak within one to two years of deposition and that, after 5 to 10 years, the mineral soil would hold the major portion of the deposited ${ }^{137} \mathrm{Cs}$ (Hashimoto et al., 2013). If correct, this implies that the window of time available to intervene in the natural cycle of radiocaesium in forests is limited to 2 to 5 years; penetration of ${ }^{137} \mathrm{Cs}$ into the deeper mineral soil will reduce the surface dose, but this material is much more difficult to remove than contaminated surface litter. However, as described above, observations of ${ }^{137} \mathrm{Cs}$ migration in a range of soils suggest a rather slow migration rate, possibly controlled by the accumulation of organic matter. 
92 In this study we investigated the downwards migration of ${ }^{137} \mathrm{Cs}$ in soils developed under two pine 93 forests in contrasting climatic zones (temperate and tropical) in which organic matter (OM) 94 accumulation is markedly different. By including ${ }^{210} \mathrm{~Pb}$ analysis in our study we aimed to test the hypothesis that the long-term migration of ${ }^{137} \mathrm{Cs}$ is coupled with $\mathrm{OM}$ accumulation in these soils. As well as providing contrasting climates and OM dynamics, our two study sites were selected because they received much lower deposition following the Chernobyl and Fukushima accidents than during atmospheric nuclear weapons tests in the 1950s and 1960s. We focussed on the fate of ${ }^{137} \mathrm{Cs}$ from nuclear weapons fallout since this has been present in soils worldwide for more than 50 years and provides the best source of information on the long-term fate of radiocaesium in forest ecosystems. 
Soil samples were collected from two pine forests - one in the British Isles and one in Thailand (geographical coordinates are given in Table 1). The British site (Boundary Plantation) is a plantation of Corsican pine (Pinus nigra) in central England, established circa 1960 (estimated standing biomass was $26 \mathrm{~kg} \mathrm{~m}^{-2}$, dry mass, at the time of sampling). It occupies a level site on a geological substrate of Sherwood sandstone (Ambrose et al., 2014); annual average temperature from 1961 - 2015 was $9.8^{\circ} \mathrm{C}$ and annual precipitation over this period was $655 \mathrm{~mm}$ (Met Office, 2017). The Thai site (Wat Ban Chan) is a plantation of Khasi pine (Pinus kesiya) established circa 1925 (estimated standing biomass was $21 \mathrm{~kg} \mathrm{~m}^{-2}$, dry mass, at the time of sampling). It is situated close to the border between Mae Hong Son and Chiang Mai provinces and occupies a slightly sloping site on a geological substrate of granite and granodiorite (Department of Mineral Resources, Thailand). The annual average temperatures for Mae Hong Son and Chiang Mai provinces, respectively, were $25.2^{\circ} \mathrm{C}$ and $25.4^{\circ} \mathrm{C}$ from $1961-1990$ and annual precipitation was $1261 \mathrm{~mm}$ and $1185 \mathrm{~mm}$ over the same period (World Meteorological Office, 2017).

\section{Soil Sampling and Treatment}

The soil at Boundary Plantation was sampled on four occasions from June 2014 to March 2015. Six randomly located points were sampled on each occasion, giving a total of 24 soil cores across an area of approximately 25 hectares of forest. Wat Ban Chan was visited in February 2016 when six randomly located points were sampled across an area of approximately 1 hectare of forest.

At each site, soil samples were taken as cylindrical cores $16.2 \mathrm{~cm}$ diameter and $20 \mathrm{~cm}$ depth at Boundary Plantation; $6.8 \mathrm{~cm}$ and $15 \mathrm{~cm}$ depth at Wat Ban Chan). The cores were extruded and cut into $1 \mathrm{~cm}$ layers with respect to soil depth from the forest floor; this was the minimum thickness which would provide sufficient sample mass for analyses. After a short period of storage at $4^{\circ} \mathrm{C}$, field moist samples were used to determine soil pH (in deionized water) and water content. Sub-samples of each layer were oven dried overnight at $105^{\circ} \mathrm{C}$ then ground sufficiently to pass through a $2 \mathrm{~mm}$ soil sieve. Dried samples were used to determine bulk density, carbon content, stable element concentrations and radionuclide activity concentrations. Total and organic carbon contents were determined in small sub-samples of soil using an elemental analyser (Flash 2000, Thermo Scientific) and a total organic carbon analyser (TOC-V, Shimadzu). The instruments were calibrated with inhouse standards and quality controlled using certified reference materials (chalky soil and peaty soil) obtained from Elemental Microanalysis, Okehampton, $\mathrm{UK}$. $\mathrm{NH}_{4}$-exchangeable and $\mathrm{HNO}_{3}$-extractable 
stable element concentrations were determined by ICP-MS (iCAP-Q ICP-MS, Thermo Fisher Scientific). The instrument was calibrated using Certiprep multi-element standards (Fisher Scientific) in $2 \%$ trace analysis grade $\mathrm{HNO}_{3}$. Internal standards comprised Sc $\left(100 \mu \mathrm{g} \mathrm{L}^{-1}\right), \mathrm{Rh}\left(20 \mu \mathrm{g} \mathrm{L}^{-1}\right)$ and $\mathrm{Ir}$

$136\left(10 \mu \mathrm{g} \mathrm{L}^{-1}\right)$ in $2 \%$ trace analysis grade $\mathrm{HNO}_{3}$; procedural blanks were prepared using appropriately diluted $\mathrm{HNO}_{3}$ and $\mathrm{NH}_{4} \mathrm{NO}_{3}$. Details of radionuclide measurements are given below. Three soil layers were selected from the region of each soil profile containing the majority of ${ }^{137} \mathrm{Cs}(5-6,7-8$ and 9-10 $\mathrm{cm}$ in Boundary Plantation soil; 1-2, 2-3 and 3-4 cm in Wat Ban Chan soil). Clay-sized ( $\leq 2 \mu \mathrm{m})$ fractions were separated from these dried and homogenised samples by low speed centrifugation, following the method developed by USGS (Poppe et al., 2001). After separation, the mineralogy of the clay-sized fractions was determined using powder X-ray diffraction (XRD). Diffraction patterns were collected for each sample using a Bruker D8 powder diffractometer operating with monochromated CuKa1 radiation in reflection mode over the $2-\theta$ range $5-50^{\circ}$ using a $0.014^{\circ} 2-\theta$ step over a period of $3 \mathrm{~h}$ in a flat plate sample holder.

\section{Measurement of Radionuclides}

147 Activity concentrations of ${ }^{137} \mathrm{Cs},{ }^{241} \mathrm{Am}$ and ${ }^{210} \mathrm{~Pb}$ were determined in seven cores from Boundary 148 Plantation; ${ }^{137} \mathrm{Cs}$ and ${ }^{210} \mathrm{~Pb}$ were determined in six cores from Wat Ban Chan $\left({ }^{241} \mathrm{Am}\right.$, used as a marker for global nuclear weapons fallout, was below detection limit in all samples from Wat Ban Chan). Sub-samples of soil were dried and homogenised, then packed into small $(5.4 \mathrm{~cm} \varnothing)$ polystyrene Petri dishes. These were sealed and left to stand for at least three weeks prior to counting to allow ingrowth of ${ }^{214} \mathrm{~Pb}$ and ${ }^{214} \mathrm{Bi}$ daughters in the ${ }^{238} \mathrm{U}$ decay chain. Samples were counted for 24 hours on a high purity germanium detector (Canberra/Mirion Technologies) shielded from ambient radiation in $10 \mathrm{~cm}$ thick, copper-lined lead 'castles'. Data were processed using Genie 2000 gamma acquisition and analysis software (Canberra Industries, 2013). Counting efficiencies for all photopeaks of interest were determined using standards with identical geometries and densities as the soil samples being counted. Standards were prepared using mixed gamma standard R08-01, supplied and certified by the National Physical Laboratory (Teddington, UK) and IAEA Certified Reference Material IAEA-447 ('Radionuclides in Moss Soil'), supplied and certified by the International Atomic Energy Agency (Vienna, Austria). Caesium-137 activity was quantified using the $661.7 \mathrm{keV}\left(\mathrm{Ba}-137 \mathrm{~m}^{\mathrm{m}}\right)$ photopeak, ${ }^{241} \mathrm{Am}$ was quantified using the $59.5 \mathrm{keV}$ photopeak and total ${ }^{210} \mathrm{~Pb}$ was quantified using the $46.5 \mathrm{keV}$ photopeak. The activities of radionuclides are presented for the time of sampling (ie. not decay corrected). Supported ${ }^{210} \mathrm{~Pb}$ was quantified indirectly using the 351.9 $\mathrm{keV}$ and $609.3 \mathrm{keV}$ photopeaks of ${ }^{214} \mathrm{~Pb}$ and ${ }^{214} \mathrm{Bi}$, respectively, assuming that the activities of these two radionuclides are equal to the activity of ${ }^{210} \mathrm{~Pb}$ when the ${ }^{226} \mathrm{Ra} \rightarrow{ }^{210} \mathrm{~Pb}$ decay chain is in equilibrium. The accuracy of this method was checked by comparing the measured activity of ${ }^{226} \mathrm{Ra}$ 
with the certified value for IAEA Certified Reference Material IAEA-447. Unsupported (ie. atmospherically-derived) ${ }^{210} \mathrm{~Pb}\left({ }^{210} \mathrm{~Pb}_{\mathrm{ex}}\right)$ was calculated by subtracting supported ${ }^{210} \mathrm{~Pb}$ from total ${ }^{210} \mathrm{~Pb}$.

\section{Estimating Ages of Accumulating Organic Matter}

Measured vertical ${ }^{210} \mathrm{~Pb}_{\mathrm{ex}}$ distributions in the soil profiles were used to estimate the ages of organic matter at different depths within each soil. The Constant Rate of Supply (CRS) model was used, as described by Appleby (1998). As leaf litter falls onto the forest floor it is subsequently covered and buried by the continuous accumulation of newer litter; the rate of burial is determined by the annual production of new litter and the rate at which the litter decomposes. Application of the CRS model to quantify this burial rate assumes a constant flux of ${ }^{210} \mathrm{~Pb}_{\mathrm{ex}}$ deposition from the atmosphere to the forest floor and that ${ }^{210} \mathrm{~Pb}$ binds strongly and irreversibly to soil organic matter on contact with the litter layer. This has been confirmed by numerous studies (eg. Vile et al., 1999) and is confirmed by the very strong relationships between ${ }^{210} \mathrm{~Pb}_{\mathrm{ex}}$ activities and soil organic carbon in both the soils studied (Figure 1). According to the CRS model, the time $t$ (years) since ${ }^{210} \mathrm{~Pb}$ was deposited to a specific soil layer is given by:

$$
t=\frac{1}{\lambda} \ln \frac{A_{t o t}}{A}
$$

where $\lambda$ is the physical decay constant of ${ }^{210} \mathrm{~Pb}\left(0.0311 \mathrm{y}^{-1}\right), A_{\text {tot }}$ is the total inventory of ${ }^{210} \mathrm{~Pb}_{\text {ex }}$ in the soil profile $\left.(\mathrm{Bq} \mathrm{m})^{-2}\right)$ and $\mathrm{A}$ is the inventory of ${ }^{210} \mathrm{~Pb}_{\mathrm{ex}}\left(\mathrm{Bq} \mathrm{m}^{-2}\right)$ below the soil layer being dated. The deposition rate of ${ }^{210} \mathrm{~Pb}_{\mathrm{ex}} I$, is calculated from $\mathrm{A}_{\text {tot }}$ and $\lambda$ (Appleby, 1998):

$$
I=\lambda A_{\text {tot }}
$$

Deposition rates ranging from $78-118 \mathrm{~Bq} \mathrm{~m} \mathrm{y}^{-2}$ were calculated for Boundary Plantation, consistent with a mean deposition rate of $113 \mathrm{~Bq} \mathrm{~m}^{-2} \mathrm{y}^{-1}$ measured in UK woodland by Likuku and Branford (2011). No measurements for ${ }^{210} \mathrm{~Pb}_{\mathrm{ex}}$ deposition rates in NW Thailand are available in the literature but, from our measurements, we calculated a range of fluxes from $65-97 \mathrm{~Bq} \mathrm{~m}^{-2} \mathrm{y}^{-1}$ at Wat Ban Chan. 
Vertical distributions of soil organic carbon and bulk density are shown in Figure 2; other selected soil characteristics are summarised in Table 1. The soil at Boundary Plantation is characterised by a well-developed surface organic layer (mor humus) with a strongly acidic $\mathrm{pH}$. Organic carbon (OC) content ranged from $32 \%$ at the surface to $2 \%$ at $17 \mathrm{~cm}$. Based on the USDA (1999) definition of $>20 \%$ OC for freely-draining soils, the uppermost $5-6 \mathrm{~cm}$ of the Boundary Plantation soil is a 'litter' or $\mathrm{O}$ horizon (Figure 2a). In contrast, $\mathrm{OC}$ in the upper $3 \mathrm{~cm}$ of the Wat Ban Chan soil ranged between 3 $-5 \%$ (Figure $2 b$ ). The differences in OC contents throughout each of the soils are reflected in the average dry bulk density profiles for each site (Figure 2c). Bulk density at Boundary plantation varied from $146 \mathrm{~kg} \mathrm{~m}^{-3}$ at the surface to $470 \mathrm{~kg} \mathrm{~m}^{-3}$ at the base of the organic layer $(5-6 \mathrm{~cm})$. Bulk density in the upper $1 \mathrm{~cm}$ layer of the Wat Ban Chan soil was $789 \mathrm{~kg} \mathrm{~m}^{-3}$; this is comparable to the bulk density at a depth of $8 \mathrm{~cm}$ in the Boundary Plantation soil. At Wat Ban Chan there was a large increase in bulk density to a maximum value of $1780 \mathrm{~kg} \mathrm{~m}^{-3}$ at $2 \mathrm{~cm}$ depth, then a reduction to a mean value of $1460 \mathrm{~kg} \mathrm{~m}^{-3}$ from 3 to $13 \mathrm{~cm}$ depth. The ranges of soil $\mathrm{pH}$ at both sites did not overlap, with Boundary Plantation having a much lower pH range than Wat Ban Chan (Table 1). The minimum pH at Boundary Plantation (3.69) occurred at $7 \mathrm{~cm}$, where well-humified organic matter was mixed with sand grains, while minimum $\mathrm{pH}$ at Wat Ban Chan (5.44) was at $9-10 \mathrm{~cm}$ depth.

The ranges of $\mathrm{NH}_{4}$-exchangeable and $\mathrm{HNO}_{3}$-extractable potassium concentrations overlapped at both sites, but maximum potassium concentrations were higher at Boundary Plantation than at Wat Ban Chan. Conversely, the Wat Ban Chan soil had much higher $\mathrm{HNO}_{3}$-extractable aluminium and iron concentrations than the Boundary Plantation soil.

211 Vertical distributions of ${ }^{137} \mathrm{Cs}$ in the soils at Boundary Plantation and Wat Ban Chan are shown in 212 Figures 3 and 4 , respectively. At Boundary Plantation, ${ }^{137} \mathrm{Cs}$ activity concentration (Bq $\left.\mathrm{kg}^{-1}\right)$ was maximal at 5-6 cm depth (Figure 3a), characterised by moderately humified organic matter and an OC content of $20 \%$ (Figure 2a). The peak inventory of ${ }^{137} \mathrm{Cs}$ (Bq $\mathrm{m}^{-2}-$ the product of the ${ }^{137} \mathrm{Cs}$ activity concentration and the soil bulk density) was located $2 \mathrm{~cm}$ deeper, at 7-8 $\mathrm{cm}$ (Figure 3b) where organic matter was more humified and $\mathrm{OC}$ was $6.3 \%$. The cumulative inventory of ${ }^{137} \mathrm{Cs}$, measured from the surface downwards, reached $50 \%$ at approximately $7 \mathrm{~cm}$ depth (Figure 3c); this represents the 'half-depth' of ${ }^{137}$ Cs migration in the Boundary Plantation soil in 2015.

The half-depth of ${ }^{137} \mathrm{Cs}$ at Wat Ban Chan was much shallower than at Boundary Plantation. Caesium-137 activity concentration $\left(\mathrm{Bq} \mathrm{kg}^{-1}\right.$ ) at Wat Ban Chan was maximal at $2-3 \mathrm{~cm}$ depth (Figure 
depth (Figure 4b) and the 'half-depth' of ${ }^{137} \mathrm{Cs}$ migration in the Wat Ban Chan soil in 2016 was $2 \mathrm{~cm}$

223 (Figure 4c).

224 Americium was detectable in some samples at Boundary Plantation but the activity concentrations 225 and inventories of ${ }^{241} \mathrm{Am}$ were much lower than those of ${ }^{137} \mathrm{Cs}$ (Figure 5). Peak activity concentration $226\left(\mathrm{~Bq} \mathrm{~kg}^{-1}\right.$; Figure $\left.5 \mathrm{a}\right)$ and peak activity inventory (Bq m${ }^{-2}$; Figure $\left.5 \mathrm{~b}\right)$ of ${ }^{241} \mathrm{Am}$ were both located at a depth of $7-8 \mathrm{~cm}$. Cumulative percentage distribution of ${ }^{241} \mathrm{Am}$ reached $50 \%$ at $7 \mathrm{~cm}$ depth; thus the observed 'half-depths' for ${ }^{241} \mathrm{Am}$ and ${ }^{137} \mathrm{Cs}$ migration in 2015 were the same. Americium-241 was entirely undetectable in the Wat Ban Chan soil samples; nuclear weapons tests produced much less ${ }^{241} \mathrm{Am}$ than ${ }^{137} \mathrm{Cs}$ and global fallout was considerably lower at this latitude.

The powder X-ray diffraction (XRD) patterns of clay-sized fractions from selected depth samples are shown in Supplementary Material (Figure S1 for Boundary Plantation and Figure S2 for Wat Ban Chan). These data were phase-matched against the International Centre for Diffraction Database (ICDD) to determine the crystalline material present and these pattern numbers are given in parentheses after each phase. Quartz (46-1045), kaolinite (06-221) and illite (26-0911) were identified in the Boundary Plantation samples while gibbsite (33-0018) was found in addition to quartz and the same clay minerals in the Wat Ban Chan samples. The XRD results suggest that the clay-sized fraction at the base of the litter layer $(5-6 \mathrm{~cm})$ at Boundary Plantation contained only amorphous, non-crystalline material (probably colloidal organic matter) although very small reflections at $24.85^{\circ}(d=3.58 \AA)$ and $26.64^{\circ}{ }^{\circ}(d=3.34 \AA)$ suggest the presence of trace quantities of kaolinite and quartz, respectively, at this depth. At depths of 7-8 cm and 9-10 cm there are strong reflections indicating the presence of both kaolinite $\left(12.32^{\circ}, d=7.18 \AA\right.$ and $24.85^{\circ}, d=3.58 \AA$ ) and quartz $\left(20.86^{\circ}, d=4.25 \AA\right.$ and $26.64^{\circ}, d=3.34 \AA$ ) in the clay-sized fraction of the soil. The only clear indication of the presence of illite $\left(17.65^{\circ}, d=5.02 \AA\right)$ can be seen at a depth of $9-10 \mathrm{~cm}$, which is below the depths of maximum ${ }^{137} \mathrm{Cs}$ activity concentration $(5-6 \mathrm{~cm})$ and activity inventory $(7-8 \mathrm{~cm})$, where illite is evidently absent.

At Wat Ban Chan (Figure S2) there were strong and consistent reflections for kaolinite $\left(12.32^{\circ}\right.$, $d=7.18 \AA ; 24.85^{\circ}, d=3.58 \AA$; $37.67^{\circ}, d=2.39 \AA$ and $\left.45.57^{\circ}, 1.99 \AA\right)$ and illite $\left(8.84^{\circ}, d=10.00 \AA \AA^{\circ} 17.65^{\circ}\right.$, $d=5.02 \AA$ and $26.67^{\circ}, d=3.34 \AA$ ) in clay-sized fractions from each soil depth analysed. In addition, gibbsite reflections $\left(18.28^{\circ}, \mathrm{d}=4.85 \AA\right.$ and $20.30^{\circ}, \mathrm{d}=4.37 \AA$ ) were clearly evident in each sample, consistent with the high $\mathrm{HNO}_{3}$-extractable $\mathrm{Al}$ in the Wat Ban Chan soil and indicating the highly weathered nature of this soil. 
253 Vertical distributions of (unsupported) ${ }^{210} \mathrm{~Pb}_{\text {ex }}$ activity concentrations $\left(\mathrm{Bg} \mathrm{kg}^{-1}\right)$ in the soils at 254 Boundary Plantation and Wat Ban Chan are shown in Figures 6(a) and 7(a), respectively. At both 255 sites, peak ${ }^{210} \mathrm{~Pb}_{\text {ex }}$ activity concentrations occurred at the soil surface (forest floor) and declined in 256 each successive depth increment, as would be expected for a radionuclide derived from continuous 257 atmospheric deposition. The CRS model (see methods) was used to construct the age-depth 258 relationships for soil organic carbon shown in Figures 6(b) and 7(b) for Boundary Plantation and Wat 259 Ban Chan, respectively. For Boundary Plantation, the age-depth curve indicates that OC in the 7-8 $260 \mathrm{~cm}$ layer, in which the highest ${ }^{137} \mathrm{Cs}$ activity inventory and 'half-depth' of ${ }^{137} \mathrm{Cs}$ migration were observed (Figure 3), accumulated in 1961, within a range from 1953 - 1969.

262 The ${ }^{210} \mathrm{~Pb}_{\text {ex }}$ activity concentration $\left(\mathrm{Bg} \mathrm{kg}^{-1}\right)$ at Wat Ban Chan decreased approximately exponentially 263 downwards from the soil surface (Figure 7a). The year of accumulation of $O C$ in the $2-3 \mathrm{~cm}$ layer 264 was estimated to be 1967, within a range from 1965 - 1969 (Figure 9b). This layer contains the 265 highest activity concentration and activity inventory of ${ }^{137} \mathrm{Cs}$ at Wat Ban Chan (Figure 4). 
Atmospheric weapons tests peaked in 1962 (UNSCEAR, 2000) and cumulative deposition from these tests in the northern hemisphere peaked around 1966 (Cambray et al., 1989). From interpolated deposition data for ${ }^{137} \mathrm{Cs}$ across the British Isles from 1955 - 1985, the average inventory in 1985 at Boundary Plantation was $2090 \mathrm{~Bq} \mathrm{~m}{ }^{-2}{ }^{137} \mathrm{Cs}$ (Wright, 2016). A survey by Horrill et al. (1988) measured an average deposition inventory from Chernobyl of $830 \mathrm{~Bq} \mathrm{~m}{ }^{-2}{ }^{137} \mathrm{Cs}$ close to Boundary Plantation (Chaplow et al., 2015). The summed weapons fallout and Chernobyl ${ }^{137} \mathrm{Cs}$ would have decayed to $1485 \mathrm{~Bq} \mathrm{~m}^{-2}$ in 2015, which agrees closely with our measured inventory in 2014-2015 of $1489 \mathrm{~Bq} \mathrm{~m}^{-2}$.

275 Few data exist on ${ }^{137}$ Cs deposition to Thailand and these are generally expressed in activity concentrations $\left(\mathrm{Bq} \mathrm{kg}^{-1}\right)$ rather than deposition inventories $\left(\mathrm{Bq} \mathrm{m}^{-2}\right)$. At Wat Ban Chan in 2016 we measured a total soil ${ }^{137} \mathrm{Cs}$ inventory of $200 \mathrm{~Bq} \mathrm{~m}^{-2}$. According to UNSCEAR (1969) the cumulative deposition up to 1968 of ${ }^{137} \mathrm{Cs}$ between latitudes $10^{\circ}$ and $20^{\circ} \mathrm{N}$ was $790 \mathrm{~Bq} \mathrm{~m}{ }^{-2}$; this would have decayed to $260 \mathrm{~Bq} \mathrm{~m}^{-2}$ by 2016. Measurements of radioactive fallout in east Asia after the Chernobyl accident showed mostly undetectable deposition of radiocaesium across the region (Cambray et al., 1987a; 1987b). Finer scale measurements of ${ }^{137}$ Cs throughout Vietnam showed 'insignificant' deposition from Chernobyl from 1986 to 1990 (Hien et al., 1994) and 'latitude mean deposition density' ranging from $237 \mathrm{~Bq} \mathrm{~m}{ }^{-2}$ south of $16^{\circ}$ latitude to $1097 \mathrm{~Bq} \mathrm{~m}^{-2}$ north of $16^{\circ}$ (Hien et al., 2002). Contribution of ${ }^{137} \mathrm{Cs}$ from Fukushima was negligible in the region: Long et al. (2012) reported a transient peak air concentration of $37 \mu \mathrm{Bq} \mathrm{m} \mathrm{m}^{-3}$ in Ho Chi Minh City, though no deposition inventories were reported. We conclude that the ${ }^{137} \mathrm{Cs}$ inventory we measured at Wat Ban Chan was derived mainly from atmospheric nuclear weapons testing, with peak deposition in the mid-1960s.

Even though both sites supported mature pine trees at similar tree densities, the difference between their respective soil organic carbon (OC) contents was striking (Figure 2a, b). Production and decomposition of tree litter is strongly dependent on latitude (Berg et al., 1999; Zhang et al., 2008) and the relative accumulation of litter and partially-humified organic matter on the forest floor represents a balance between these processes. Litter production is significantly higher in more southerly latitudes, but the rate of decomposition in tropical forests such as Wat Ban Chan is high enough to prevent any appreciable accumulation of non- or partially-humified material on the forest floor. Conversely, significant accumulation of litter and forest floor materials is typical of temperate and boreal forests due to comparatively low rates of decomposition (Berg, 2014). Given the greatly contrasting organic matter accumulation rates at our two study sites, the accumulation of 
substantially compressed compared with the Boundary Plantation soil. Hence, the period of time represented by $1 \mathrm{~cm}$ depth in the upper part of the Wat Ban Chan soil (Figure 7b) is considerably greater than $1 \mathrm{~cm}$ depth in the Boundary Plantation soil's organic layer (Figure 6b).

Distributions of atmospherically derived radionuclides such as ${ }^{210} \mathrm{~Pb}_{\text {ex }}$ and ${ }^{241} \mathrm{Am}$ are invaluable diagnostic tools when interpreting ${ }^{137} \mathrm{Cs}$ distributions. In analysing our data we made the assumption that, after deposition, ${ }^{210} \mathrm{~Pb}_{\mathrm{ex}}$ is inextricably bound to the organic matter (OM) it first comes into contact with on the forest floor (ie. litter). There is strong evidence to support this assumption. Vile et al. (1999) conducted experiments which showed that the binding of soluble $\left(\mathrm{Pb}^{2+}\right)$ and particulate lead to peat is strong and stable under varying moisture content regimes. Dorr and Munnich (1989) demonstrated that the rates of downwards transfer of $\mathrm{OM}$ and ${ }^{210} \mathrm{~Pb}$ in forest soils are identical, concluding that ${ }^{210} \mathrm{~Pb}$ is carried by $\mathrm{OM}$ and is thus a good indicator of the movement of the OM. More recently, Teramage et al. (2015) have proposed the use of ${ }^{210} \mathrm{~Pb}$ as a reliable tracer for the cycling of $\mathrm{OM}$ in forests, based on the strong correlations they observed in ${ }^{210} \mathrm{~Pb}$ and $\mathrm{OM}$ distributions vertically (in soil profiles) and horizontally in a Japanese cypress (Cryptomeria japonica) forest. Our data confirm that ${ }^{210} \mathrm{~Pb}_{\mathrm{ex}}$ and $\mathrm{OC}$ are significantly correlated at both of our sampling sites (Figure 1a, b). Am-241 should also be strongly bound to OM since it exists in the $3+$ oxidation state and forms strong complexes with the dominant functional groups on OM. Gil-Garcia et al. (2009b) presented a geometric mean solid-liquid $\mathrm{K}_{d}$ value of $2500 \mathrm{~L} \mathrm{~kg}^{-1}$ for ${ }^{241} \mathrm{Am}$ in organic soils, with a maximum value of $110,000 \mathrm{~L} \mathrm{~kg}^{-1}$. Thus, ${ }^{241} \mathrm{Am}$ should provide a marker for the fate of $\mathrm{OM}$ as it is progressively decomposed and transported down the soil profile. However, ${ }^{241} \mathrm{Am}$ in soils is partly derived from direct deposition and partly from in-growth resulting from physical decay of ${ }^{241} \mathrm{Pu}$, which makes it difficult to determine its exact residence time in specific soil layers. Furthermore, an analysis of literature by Coughtrey et al. (1984) concluded that ${ }^{241} \mathrm{Am}$ is potentially more mobile than Pu in acidic soils, suggesting that it may not be fully retained by solid-phase OM in acid forest soils.

Given the deposition history described above, ${ }^{137} \mathrm{Cs}$ derived from nuclear weapons fallout is the most appropriate tracer to study the long-term fate of radiocaesium in natural ecosystems, since it has been present in the environment for at least 50 years. Due to the large differences in vertical gradients of bulk densities in the soils at Boundary Plantation and Wat Ban Chan (Figure 2c) the peak activity inventories $\left(\mathrm{Bq} \mathrm{m}^{-2}\right.$ ) and half-depths provide the most reliable measures of the vertical migration of ${ }^{137} \mathrm{Cs}$ since deposition. Peak ${ }^{137} \mathrm{Cs}$ inventory and half-depth of ${ }^{137} \mathrm{Cs}$ at Boundary Plantation were both located at 7-8 cm, measured from the surface of the litter layer (ie. the forest floor). This was $2 \mathrm{~cm}$ below the 'litter' or O horizon (according to the USDA, 1999, definition - see Figure $2 \mathrm{a}$ ) but the OC content was still relatively high (6.3\%) at this depth. Some sand grains were 
visible in these samples and there were small reflections attributable to quartz in the X-ray diffractograms of sub-2 $\mu \mathrm{m}$ material from this depth (Figure S1). Kaolinite reflections were also evident but there was no indication of illite as a component of the clay-sized fraction at this depth. A weak illite reflection at $17.65^{\circ}$ was evident at a depth of 9-10 cm, accompanied by much stronger quartz and kaolinite reflections illustrating the increasing mineral content of the soil $2 \mathrm{~cm}$ below the depth of peak ${ }^{137} \mathrm{Cs}$ accumulation (4.6\% OC). Co-located with the peak inventory and half-depth of ${ }^{137} \mathrm{Cs}$ were the peak inventory and half-depth of ${ }^{241} \mathrm{Am}$ (Figure $5 \mathrm{~b}, \mathrm{c}$ ). The source of ${ }^{241} \mathrm{Am}$ is global nuclear weapons fallout since no ${ }^{241} \mathrm{Am}$ (or plutonium, including ${ }^{241} \mathrm{Pu}$ which decays to ${ }^{241} \mathrm{Am}$ ) from Chernobyl was measured at this site; on this basis the depth of peak ${ }^{137} \mathrm{Cs}$ accumulation can be dated to the global weapons fallout era. More precise evidence for the age of this depth of the forest soil is provided by the ${ }^{210} \mathrm{~Pb}_{\text {ex }}$ profile in Figure 6(a) and the accompanying age-depth profile in Figure 6(b). This provides a date of 1961 (within a range of $1953-1969$ ) for the depth of peak ${ }^{137} \mathrm{Cs}$ accumulation at Boundary Plantation, which is clearly within the global nuclear weapons fallout era. Based on our assumption that ${ }^{210} \mathrm{~Pb}_{\mathrm{ex}}$ is a reliable marker of $\mathrm{OM}$ accumulation, this evidence suggests that ${ }^{137} \mathrm{Cs}$ deposited at Boundary Plantation in the 1960 s has migrated at the same rate as the OM which accumulated on the forest floor at the time of peak global weapons fallout. It is striking that this migration has not been more pronounced given the absence of illite in the layer of peak ${ }^{137} \mathrm{Cs}$ accumulation; fixation by illite has evidently not been the key mechanism of retention of ${ }^{137} \mathrm{Cs}$ in the soil at this site.

In contrast, the soil at Wat Ban Chan showed clear X-ray reflections for illite in the sub-2 $\mu \mathrm{m}$ fractions extracted from the layer of peak ${ }^{137} \mathrm{Cs}$ accumulation and the layers immediately above and below. Peak accumulation and half-depth of ${ }^{137} \mathrm{Cs}(2-3 \mathrm{~cm})$ were both much shallower than at Boundary Plantation; this probably reflects the strong retention of ${ }^{137} \mathrm{Cs}$ by illite in the denser, more mineral soil at Wat Ban Chan. As described above, the uppermost $3 \mathrm{~cm}$ at the surface of the Wat Ban Chan soil represents a compressed chronology of OC accumulation when compared with Boundary Plantation, which can be seen by comparing Figures $6 \mathrm{~b}$ and $7 \mathrm{~b}$, respectively. No ${ }^{241} \mathrm{Am}$ was detectable at Wat Ban Chan, but an exponential depth profile of ${ }^{210} \mathrm{~Pb}_{\text {ex }}$ (Figure 7a) provided an age-depth relationship (Figure 7b) that firmly dated the peak accumulation of ${ }^{137} \mathrm{Cs}$ to the era of maximum global nuclear weapons fallout (1967, within the range 1965-1969). The precision of this date illustrates the applicability of ${ }^{210} \mathrm{~Pb}_{\mathrm{ex}}$ as a means of dating $\mathrm{OC}$ accumulation in forest topsoil and also the strong sorptive capacity for radiocaesium of the topsoil at Wat Ban Chan.

Dorr and Munnich (1989) quantified the downwards migration of ${ }^{137} \mathrm{Cs}$ from global weapons fallout in German forest soils in 1987 (correcting for the contribution of ${ }^{137} \mathrm{Cs}$ from Chernobyl) and concluded that ${ }^{137} \mathrm{Cs}$ had migrated slightly faster than solid-phase OM because caesium partitions 
between solid and liquid phases within the soil. They also concluded that, in forest soils rich in organic matter, "ion exchange (of ${ }^{137} \mathrm{Cs}$ ) on mineral soil particles is of minor influence" and that mobilisation of ${ }^{137} \mathrm{Cs}$ in such soils is largely due to soluble OC; this is supported by evidence from Agapkina et al. (1995). Our ${ }^{210} \mathrm{~Pb}_{\mathrm{ex}}$ date of 1961 for the soil layer in which peak ${ }^{137} \mathrm{Cs}$ accumulation was observed at Boundary Plantation generally supports these conclusions: in other words, ${ }^{137} \mathrm{Cs}$ deposited in the mid-1960s has migrated to a layer of solid organic material which accumulated in the early 1960s. Similarly, peak ${ }^{241} \mathrm{Am}$ activity in the same soil layer at Boundary Plantation suggests that this radionuclide has also migrated (to a small extent) with soluble $O C$ rather than being retained entirely by solid-phase OM. It is clear, however, that both ${ }^{137} \mathrm{Cs}$ and ${ }^{241} \mathrm{Am}$ deposited in the mid-1960s have remained predominantly associated with OM that was introduced to the soil as litter fall in the same period.

Immobilisation of radiocaesium in soils is known to be controlled primarily by highly specific interaction with 2:1 clay minerals, especially illite. Our observations and conclusions from the Wat Ban Chan site agree with this precept: however, the results from Boundary Plantation are less easily explained. Caesium is known to sorb weakly and non-specifically to organic matter in soils. GilGarcia et al. (2009a) proposed a geometric mean solid-liquid $K_{d}$ value of $270 \mathrm{~L} \mathrm{~kg}^{-1}$ for caesium in organic soils; however, they also proposed a maximum $\mathrm{K}_{\mathrm{d}}$ value of $95000 \mathrm{~L} \mathrm{~kg}^{-1}$ that indicates that sorption of caesium can be very strong in some organic soils. Rigol et al. (1998) investigated four soils ranging from $46 \%$ to $99 \%$ OM and concluded that radiocaesium sorption could be attributed to small quantities of illite in three of them; the exception was a soil with $99 \% \mathrm{OM}$. It is possible that, even though XRD analyses of Boundary Plantation soil showed an absence of illite in the layer of peak ${ }^{137} \mathrm{Cs}$ accumulation, very small (undetectable) quantities of illite may have been present and could have been sufficient to retain the bulk of ${ }^{137} \mathrm{Cs}$ in the layer of $\mathrm{OM}$ in which it was originally deposited. This is unlikely, however; powder X-ray diffraction is extremely sensitive for phyllosilicates when carried out in reflection mode because powder diffraction patterns of the clay minerals are prone to preferred orientation effects. The flat plate sample holder facilitates the alignment of the platy crystals with one another and the sample holder in a non-random arrangement. As only polycrystalline materials with individual crystals randomly oriented to the incident beam attain the expected intensity ratios calculated from the crystal structure, this arrangement of ordering of the platy crystals causes reflections originating from the well-ordered and aligned layers to be significantly enhanced compared with those that originate from the ordering between the layers and/or other materials not showing this effect. This means that very small quantities below the detection limit of $\sim 3 \%$ can be observed from materials which contain these phases. However, even if such small quantities of illite were present, it has been shown that 
clays in combination with $\mathrm{OM}$ may not experience the lattice collapse which is necessary to fix Cs as strongly as in mineral soils (Hird et al., 1996). Kruyts and Delvaux (2002) have described how accumulating $\mathrm{OM}$ in forest soils acts to 'dilute' the specific sorption of radiocaesium by frayed edge sites on micaceous clay minerals.

Some authors have suggested that there is a significant biological role in the retention of ${ }^{137} \mathrm{Cs}$ in organic soils (Sanchez et al., 2000). Tegen et al. (1991) observed that migration of caesium in forest soil columns was altered by increasing the incubation temperature which resulted in an increase in microbial decomposition rate. Rafferty et al. (2000) observed that, 10 years after Chernobyl, downwards physical migration of ${ }^{137} \mathrm{Cs}$ in pine forest soils was 'countered' by uptake and translocation in plant roots and fungal mycelia. This seems to be a longer-term characteristic of radiocaesium behaviour; one year after the Fukushima accident Koarashi et al. (2012) found no evidence that the extractability of ${ }^{137} \mathrm{Cs}$ in forest soils was affected by chloroform fumigation which would have released any biologically-held radiocaesium. The same lead author, however, found that

${ }^{137} \mathrm{Cs}$ from the Fukushima accident was retained in the surface organic layer of a Japanese Cypress (Cryptomeria japonica) forest much more effectively than in the organic layer in a deciduous forest soil (Koarashi et al., 2016). Prior to the Fukushima accident, Takenaka et al. (1998) found strong correlations between OM and weapons fallout ${ }^{137} \mathrm{Cs}$ in forest soils under hinoki (Chamaecyparis obtusa) and red pine (Pinus densiflora). Koarashi et al. (2016) concluded that the forest type plays an important role in controlling the downwards migration of ${ }^{137} \mathrm{Cs}$ through the soil. Since different forest types are characterised by different soil OM dynamics it is probable that this is the key variable that results in the observed differences in ${ }^{137} \mathrm{Cs}$ behaviour between different forest soils.

\section{Conclusions}

Our results provide evidence that, even under strikingly different climatic regimes, the long-term (50 year) downwards migration of ${ }^{137} \mathrm{Cs}$ in coniferous (pine) forest soil is limited to a few $\mathrm{cm}$ and linked to $\mathrm{OM}$ accumulation and migration. Migration was particularly limited in a tropical pine forest soil (Wat Ban Chan, Thailand) in which fixation by illite is the most likely retention mechanism, though a high bulk density may also have helped to limit vertical migration of ${ }^{137} \mathrm{Cs}$ here. Even at this site, the majority of ${ }^{137} \mathrm{Cs}$ remains associated with the $\mathrm{OM}$ present when it was deposited; ${ }^{210} \mathrm{~Pb}_{\mathrm{ex}}$ associated with $\mathrm{OM}$ allows the precise dating of the ${ }^{137} \mathrm{Cs}$ here to the global nuclear weapons fallout era. In the more highly organic soil underlying the temperate pine forest (Boundary Plantation, UK) some limited vertical movement of weapons fallout ${ }^{137} \mathrm{Cs}$ has occurred, but the layer of peak ${ }^{137} \mathrm{Cs}$ accumulation is still relatively shallow $(7-8 \mathrm{~cm})$ and clearly co-located with OM originating at the time of global weapons testing. The absence of measurable illite in this layer suggests that retention 
434 is due to the effects of non-specific sorption to OM, possibly coupled with biological uptake and 435 recycling. Furthermore, while the penetration of the temperate pine forest soil profile by ${ }^{137} \mathrm{Cs}$ to a 436 depth of 7-8 cm can be interpreted as downwards 'transport' following deposition, it is in large part 437 due to the accumulation of organic matter above the deposited radiocaesium. The lack of significant 438 migration over a 50 year period at both sites has important consequences for long-term forest 439 management and radiation doses to humans and other organisms in forests. Models of long-term 440 radiocaesium migration in forest soils should explicitly account for the role of OM in this process, 441 especially when considering forests under contrasting climatic regimes. 
443 We thank the Forestry Commission (UK) and the Wat Chan Royal Project Development Center 444 (Thailand) for granting access to the field sampling sites. Dr Saul Vazquez Reina carried out organic 445 carbon analyses and separation of clay-sized fractions of soils. Itthipoonthanakorn thanks the Thai 446 Government and Office of Atoms for Peace (Bangkok) for financial support during this study.

Author Contributions

$451 \mathrm{TI}$ and GS carried out all field work and TI carried out laboratory work, including radiometric analysis.

452 SD carried out XRD analysis and interpretation and NC contributed to interpretation of Pb-210 ages.

453 GS and TI wrote the main text and all authors reviewed the manuscript.

454

455

456

457 Competing Financial Interests Statement

458 The authors declare no competing financial interests. 
1. Agapkina, G. I., F. A. Tikhomirov, A. I. Shcheglov, W. Kracke \& K. Bunzl (1995) Association of Chernobyl-derived ${ }^{239+240} \mathrm{Pu},{ }^{241} \mathrm{Am},{ }^{90} \mathrm{Sr}$ and ${ }^{137} \mathrm{Cs}$ with organic matter in the soil solution. Journal of Environmental Radioactivity, 29 (3), 257-269.

2. Almgren, S. \& M. Isaksson (2006) Vertical migration studies of Cs-137 from nuclear weapons fallout and the Chernobyl accident. Journal of Environmental Radioactivity, 91, 90 - 102.

3. Ambrose, K, Hough, E, Smith, N J P \& Warrington, G. 2014. Lithostratigraphy of the Survey Research Report, RR/14/01.

4. Appleby, P. G. (1998) Dating recent sediments by ${ }^{210} \mathrm{~Pb}$ : problems and solutions. In: Illus, E. (ed.); Radiation and Nuclear Safety Authority, Helsinki (Finland); 151 p, STUK-A145, 7-24.

5. Berg, B. (2014) Foliar Litter Decomposition: A Conceptual Model with Focus on Pine (Pinus) Litter-A Genus with Global Distribution. ISRN Forestry, Review Article, Article ID 838169, $22 \mathrm{pp}$.

6. Berg, B., A. Albrektson, M. Berg, J. Cortina, M-B. Johansson, A. Gallardo, M. Madeira, J. Pausas, W. Kratz, R. Vallejo \& C. McClaugherty (1999) Amounts of litter fall in some pine forests in a European transect, in particular Scots pine. Annals of Forest Science, 56, 625 639.

7. Bunzl, K., H. Forster, W. Kracke \& W. Schimmack (1994) Residence times of fallout ${ }^{239+240} \mathrm{Pu}$, ${ }^{238} \mathrm{Pu},{ }^{241} \mathrm{Am}$ and ${ }^{137} \mathrm{Cs}$ in the upper horizons of an undisturbed grassland soil. Journal of Environmental Radioactivity, 22, 11 - 27.

8. Cambray, R. S., P. A. Cawse, J. A. Garland, J. A. B. Gibson, P. Johnson, G. N. J. Lewis, D. Newton, L. Salmon \& B. O. Wade (1987a) Observations on radioactivity from the Chernobyl accident. Harwell Report, AERE, R 12462, 66 pp.

9. Cambray, R. S., K. Playford, G. N. J. Lewis \& P. J. Burton (1987b) Radioactive fallout in air and rain: results for 1985 and 1986. Harwell Report, AERE, R 12872, 26 pp.

10. Cambray, R. S., K. Playford, G. N. J. Lewis \& R. C. Carpenter (1989) Radioactive fallout in air and rain: results to the end of 1987. Harwell Report, AERE, R 13226, 24 pp.

11. Chaplow, J.S., Beresford, N.A. \& Barnett, C.L. (2015) Post Chernobyl surveys of radiocaesium in soil, vegetation, wildlife and fungi in Great Britain. Earth Syst. Sci. Data, 7, 215-221.

12. Coughtrey, P. J., D. Jackson, C. H. Jones and M. C. Thorne (1984) Radionuclide distribution and transport in terrestrial and aquatic systems, Balkema, Rotterdam, Volume V. 
13. Department of Mineral Resources, Thailand. http://www.dmr.go.th/download/pdf/North/Chiangmai.pdf. Accessed 30 ${ }^{\text {th }}$ November 2017.

14. Dorr, H. \& K. O. Munnich (1989) Downward movement of soil organic matter and its Influence on trace-element transport $\left({ }^{210} \mathrm{~Pb},{ }^{137} \mathrm{Cs}\right)$ in the soil. Radiocarbon, 31(3), $655-663$.

15. Dumat, C. \& S. Staunton (1999) Reduced adsorption of caesium on clay minerals caused by various humic substances. Journal of Environmental Radioactivity, 46, 187-200.

16. Gil-Garcia, A. Rigol \& M. Vidal (2009a) New best estimates for radionuclide solid-liquid distribution coefficients in soils, Part 1: radiostrontium and radiocaesium

17. Gil-Garcia, A. Rigol \& M. Vidal (2009b) New best estimates for radionuclide solid-liquid distribution coefficients in soils, Part 2

18. Hashimoto, S., S. Ugawa, K. Nanko \& K. Shichi (2012) The total amounts of radioactively contaminated materials in forests in Fukushima, Japan. Scientific Reports, 2, 416.

19. Hashimoto, S., T. Matsuura, K. Nanko, I. Linkov, G. Shaw \& S. Kaneko (2013) Predicted spatio-temporal dynamics of radiocesium deposited on forests following the Fukushima nuclear accident. Scientific Reports, 3, 2564.

20. Hien, P. S., Binh, P. N., Truong, N. N., Bac, V. T. \& Ngo, N. T. (1994) Variations of caesium isotope concentrations in air and fallout at Dalat, South Vietnam, 1986-91. Journal of Environmental Radioactivity, 22, 55-62.

21. Hien, P.D. , H.T. Hiep, N.H. Quang, N.Q. Huy, N.T. Binh, P.S. Hai, N.Q. Long \& V.T. Bac (2002) Derivation of ${ }^{137} \mathrm{Cs}$ deposition density from measurements of ${ }^{137} \mathrm{Cs}$ inventories in undisturbed soils. Journal of Environmental Radioactivity, 62, 295 - 303.

22. Hird, A. B., D.L. Rimmer \& F.R. Livens (1996) Factors affecting the sorption and fixation of caesium in acid organic soil. European Journal of Soil Science, 47(1), 97-104.

23. Horrill, A. D., V. W. Lowe \& G. Howson (1988) Chernobyl Fallout in Great Britain, Final report. TFS Project T07006e1. Department of the Environment. Institute of Terrestrial Ecology, Grange-over-Sands.

24. Isaksson, M., B. Erlandsson \& S. Mattsson (2001) A 10-year study of the ${ }^{137}$ Cs distribution in soil and a comparison of Cs soil inventory with precipitation-determined deposition. Journal of Environmental Radioactivity, 55, 47 - 59.

25. Ivanov, Y, A., N. Lewyckyj, S. E. Levchuk, B. S. Prister, S. K. Firsakova, N. P. Arkhipov, A. N. Arkhipov, S. V. Kruglov, R. M. Alexakhin, J. Sandalls \& S. Askbrant (1997) Migration of ${ }^{137} \mathrm{CS}$ and ${ }^{90} \mathrm{Sr}$ from Chernobyl Fallout in Ukrainian, Belarussian and Russian Soils. Journal of Environmental Radioactivity, 35(1), 1 - 21. 
26. Jagercikova, M., S. Cornu, C. Le Bas \& O. Evrard (2015) Vertical distributions of ${ }^{137}$ Cs in soils: a meta-analysis. J. Soils Sediments, 15 (1), 81-95.

27. Kirchner, G., Strebl, F., Bossew, P., Ehlken, S. \& Gerzabek, M. H. (2009) Vertical migration of radionuclides in undisturbed grassland soils. Journal of Environmental Radioactivity, 100, 716-720.

28. Koarashi, J., K. Moriya, M. Atarashi-Andoh, T. Matsunaga, H. Fujita \& M. Nagaoka (2012) Retention of potentially mobile radiocesium in forest surface soils affected by the Fukushima nuclear accident. Scientific Reports, 2, 1005.

29. Koarashi, J., M. Atarashi-Andoh, T. Matsunaga \& Y. Sanada (2016) Forest type effects on the retention of radiocesium in organic layers of forest ecosystems affected by the Fukushima nuclear accident. Scientific Reports, 6, 38591.

30. Kruyts, N. \& B. Delvaux (2002) Soil organic horizons as a major source for radiocesium biorecycling in forest ecosystems. Journal of Environmental Radioactivity, 58, 175-190.

31. Likuku, A. S. \& D. Branford (2011) Deposition rates of atmospheric particulates determined from ${ }^{210} \mathrm{~Pb}$ measurements in soils and air. Polish Journal of Environmental Studies, 20(2), 405-410.

32. Long, N.Q., Y. Truong, P.D. Hien, N.T. Binh, L.N. Sieu, T.V. Giap \& N.T. Phan (2012) Atmospheric radionuclides from the Fukushima Dai-ichi nuclear reactor accident observed in Vietnam. Journal of Environmental Radioactivity, 111, 53-8.

33. Met Office (2017) www.metoffice.gov.uk/hadobs/hadcet/index.html. Accessed $19^{\text {th }}$ October 2017.

34. Poppe, L. J., V. F. Paskevich, J. C. Hathaway \& D. S. Blackwood (2001) A Laboratory Manual for X-Ray Powder Diffraction. U.S. Geological Survey Open-File Report 01-041. http://pubs.usgs.gov/openfile/of01-041/index.htm.

35. Rafferty, B., M. Brennan, D. Dawson \& D. Dowding (2000) Mechanisms of 137Cs migration in coniferous forest soils. Journal of Environmental Radioactivity, 48, 131-143.

36. Rigol., A., M. Vidal, G. Rauret, C. Shand \& M. Cheshire (1998) Competition of Organic and Mineral Phases in Radiocesium Partitioning in Organic Soils of Scotland and the Area near Chernobyl. Environmental Science and Technology, 32, 663-669.

37. Rosen, K., M. Vinichuk \& K. J. Johanson (2009) Cs-137 in a raised bog in central Sweden. Journal of Environmental Radioactivity, 100, 534-539.

38. Sanchez, A L., N.R. Parekh, B.A. Dodd \& P. Ineson (2000) Microbial component of radiocaesium retention in highly organic soils. Soil Biology and Biochemistry, 32(14), 20912094. 
39. Schimmack, W. \& F. Marquez (2006) Migration of fallout radiocaesium in a grassland soil from 1986 to 2001 Part II: Evaluation of the activity-depth profiles by transport models. Science of the Total Environment, 368, 863-874.

40. Smith, J. T. \& N. A. Beresford (2005) Chernobyl: Catastrophe and Consequences. Praxis, Springer.

41. Takenaka, C., Y. Onda \& Y. Hamajima (1998) Distribution of cesium-137 in Japanese forest soils: Correlation with the contents of organic carbon. The Science of the Total Environment, 222, 193 - 199.

42. Tegen, I., H. Dörr \& K. O. Münnich (1991) Laboratory experiments to investigate the influence of microbial activity on the migration of cesium in a forest soil. Water Air \& Soil Pollution, 57(1), 441-447.

43. Teramage, M. T., Y. Onda, Y. Wakiyama, H. Kato, T. Kandad \& K. Tamura (2015) Atmospheric ${ }^{210} \mathrm{~Pb}$ as a tracer for soil organic carbon transport in a coniferous forest. Environmental Science - Processes \& Impacts, 17, 110 - 119.

44. UNSCEAR (1969) Report of the United Nations Scientific Committee on the Effects of Atomic Radiation, General Assembly official records: twenty-fourth session, supplement no. 13 (A/7613). United Nations, New York.

45. UNSCEAR (2000) United Nations Scientific Committee on the Effects of Atomic Radiation, New York, NY (United States). Sources and effects of ionizing radiation UNSCEAR 2000 report to the General Assembly, with scientific annexes Volume I: Sources. United Nations (UN).

46. USDA (1999) Soil Taxonomy - A Basic System of Soil Classification for Making and Interpreting Soil Surveys. United States Department of Agriculture, Agriculture Handbook No. 436, Natural Resources Conservation Service. $2^{\text {nd }}$ Edition.

47. Vile, M., R. Kelman Wieder \& M. Novak (1999) Mobility of Pb in Sphagnum-derived peat. Biogeochemistry, 45, 35-52.

48. World Meteorological Office (2017) WMO Country Profile Database Portal, www.wmo.int/cpdb/. Accessed $19^{\text {th }}$ October 2017.

49. Wright, S. M. (2016) Predicted Caesium-137 deposition from atmospheric nuclear weapons tests. NERC Environmental Information Data Centre, made available under the terms of the Open Government Licence (http://eidc.ceh.ac.uk/administration-folder/tools/ceh-standardlicence-texts/cehOGL/plain).

50. Zhang, D., D. Hui, Y. Luo \& G. Zhou (2008) Rates of litter decomposition in terrestrial ecosystems: global patterns and controlling factors. Journal of Plant Ecology, 1(2), 85 - 93. 
Table 1: Soil properties at the two study sites (to 3 significant figures).

\begin{tabular}{|l|l|l|l|l|l|l|}
\hline Sampling Site & $\begin{array}{l}\text { Location } \\
\text { (decimal } \\
\text { degrees) }\end{array}$ & $\mathrm{pH}$ & $\begin{array}{l}\text { Total (acid- } \\
\text { extractable) } \\
\text { potassium } \\
\left(\mathrm{mg} \mathrm{kg}^{-1} \mathrm{DW}\right)\end{array}$ & $\begin{array}{l}\text { Exchangeable } \\
\text { potassium } \\
\left(\mathrm{mg} \mathrm{kg}^{-1} \mathrm{DW}\right)\end{array}$ & $\begin{array}{l}\text { Acid- } \\
\text { extractable } \\
\text { Al } \\
\left(\mathrm{mg} \mathrm{kg}^{-1} \mathrm{DW}\right)\end{array}$ & $\begin{array}{l}\text { Acid- } \\
\text { extractable } \\
\text { Fe } \\
\left.\text { (mg kg }{ }^{-1} \mathrm{DW}\right)\end{array}$ \\
\hline $\begin{array}{l}\text { Boundary } \\
\text { Plantation }\end{array}$ & $\begin{array}{l}53.2135^{\circ} \mathrm{N} \\
1.0999^{\circ} \mathrm{W}\end{array}$ & $\begin{array}{l}3.69- \\
4.12\end{array}$ & $234-793$ & $33.0-536$ & $\begin{array}{l}896- \\
1820\end{array}$ & $\begin{array}{l}1840- \\
6290\end{array}$ \\
\hline $\begin{array}{l}\text { Wat Ban } \\
\text { Chan }\end{array}$ & $\begin{array}{l}19.0650^{\circ} \mathrm{N} \\
98.3155^{\circ} \mathrm{E}\end{array}$ & $\begin{array}{l}5.44- \\
6.22\end{array}$ & $214-389$ & $90.4-331$ & $\begin{array}{l}16400- \\
27500\end{array}$ & $\begin{array}{l}11700- \\
16100\end{array}$ \\
\hline
\end{tabular}


(a)

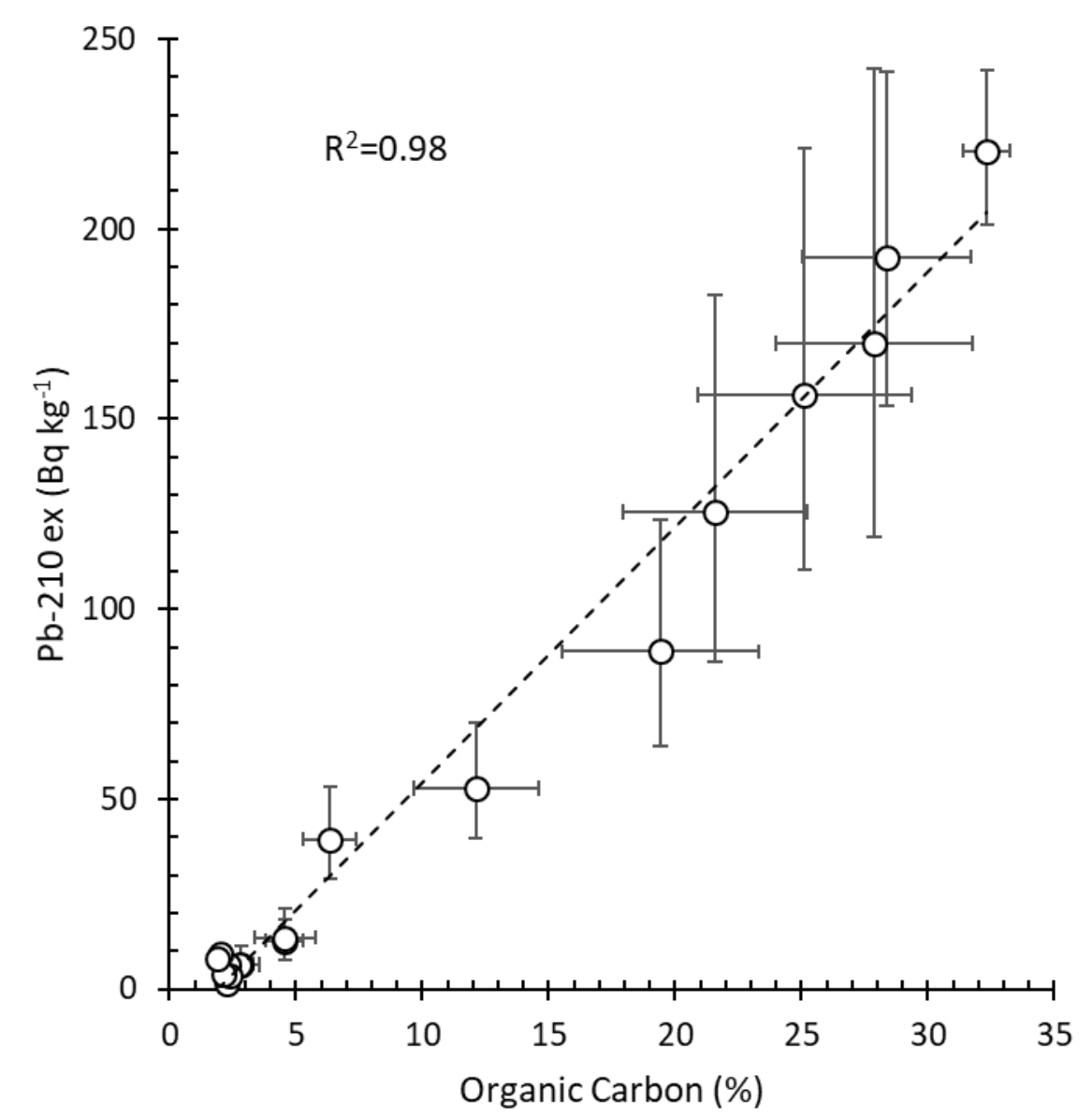

(b)

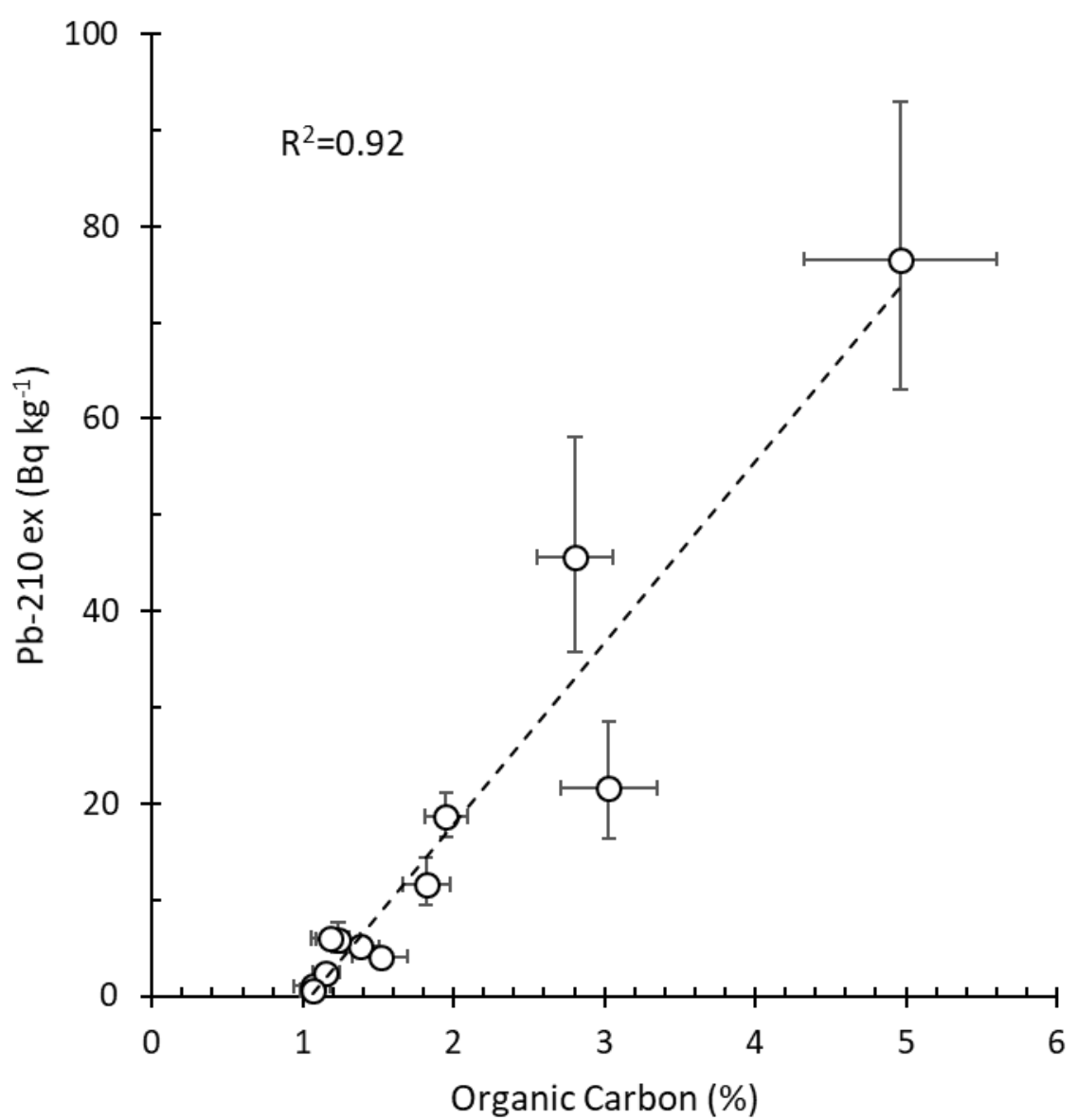

Figure 1: Relationships between organic carbon (\% by weight) and ${ }^{210} \mathrm{~Pb}$ ex activity concentrations (Bq/ $\mathrm{kg}$ ) in (a) Boundary Plantation and (b) Wat Ban Chan. Points are means, vertical and horizontal bars are SEM ( $n=7$ for Boundary Plantation, $n=6$ for Wat Ban Chan). 
(a)

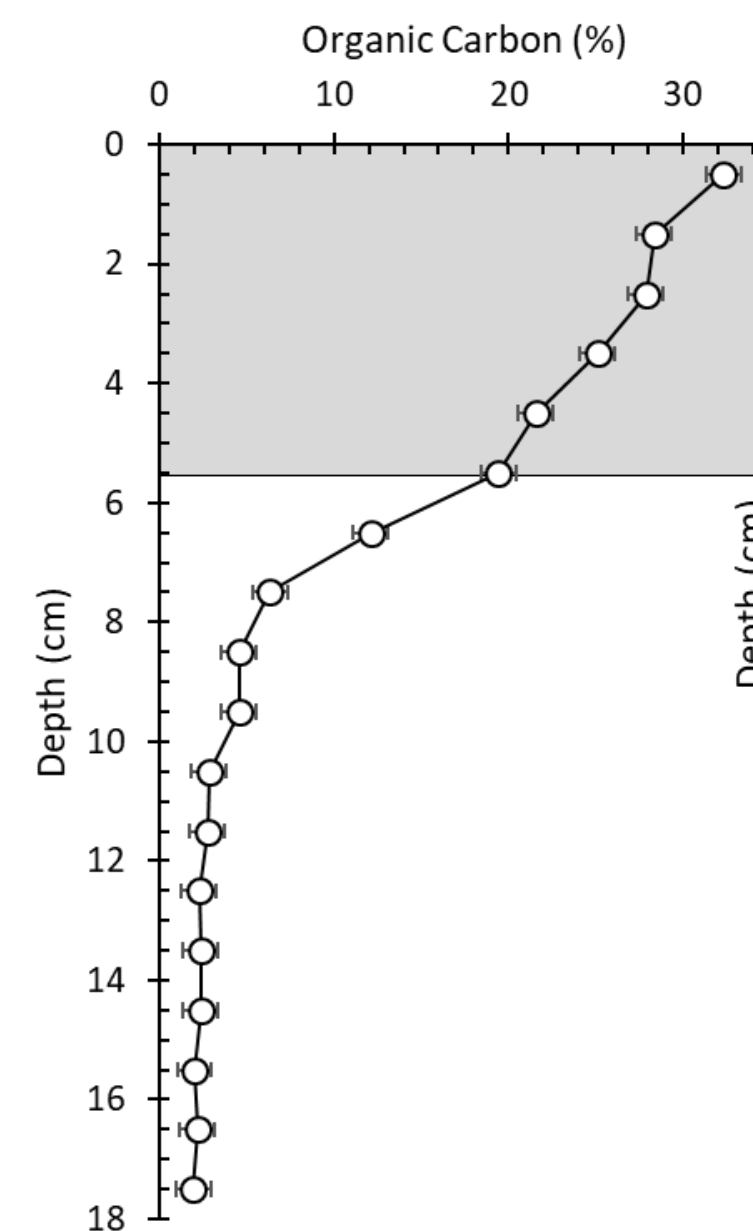

(b)

(c)

Figure 2: Depth profiles of organic carbon (\% by weight) at (a) Boundary Plantation and (b) Wat Ban Chan. (c) shows depth profiles of bulk densities for both sites. Points are means; horizontal bars are SEM based on inter-sample variation ( $n=24$ for $B P, n=6$ for WBC). The grey shaded area in (a) represents the litter or O horizon, based on the USDA definition of $>\mathbf{2 0} \%$ organic carbon (USDA, 1999). Each point represents the mid-point of a $1 \mathrm{~cm}$ soil layer.

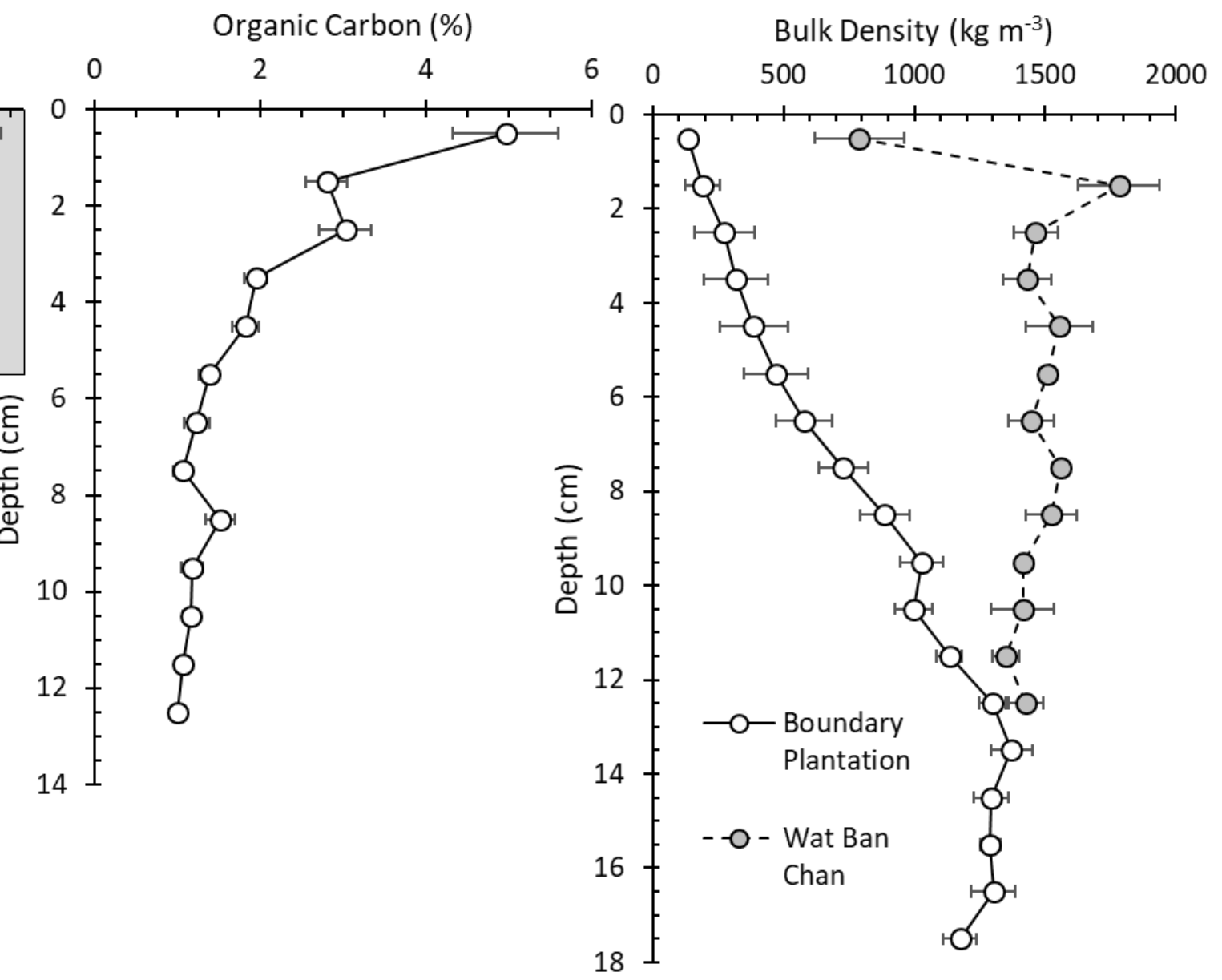


(a)

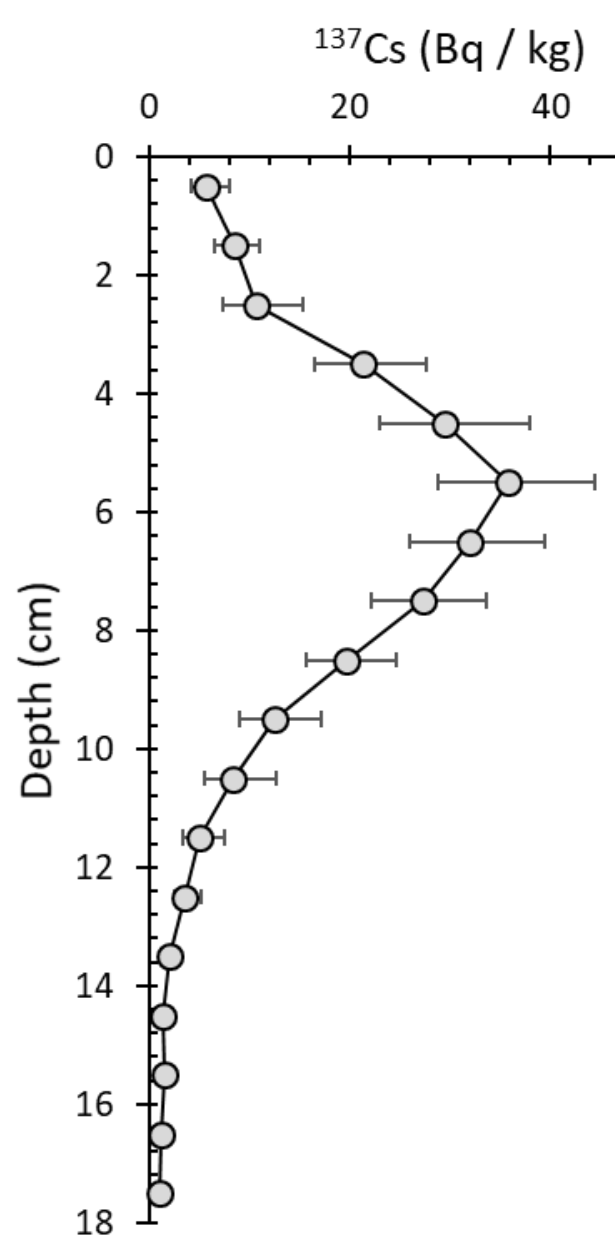

(b)

(c)

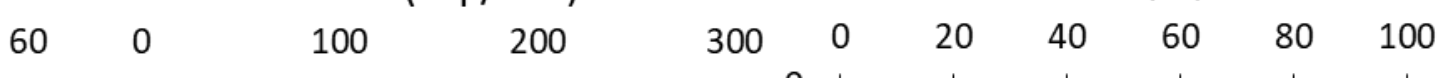

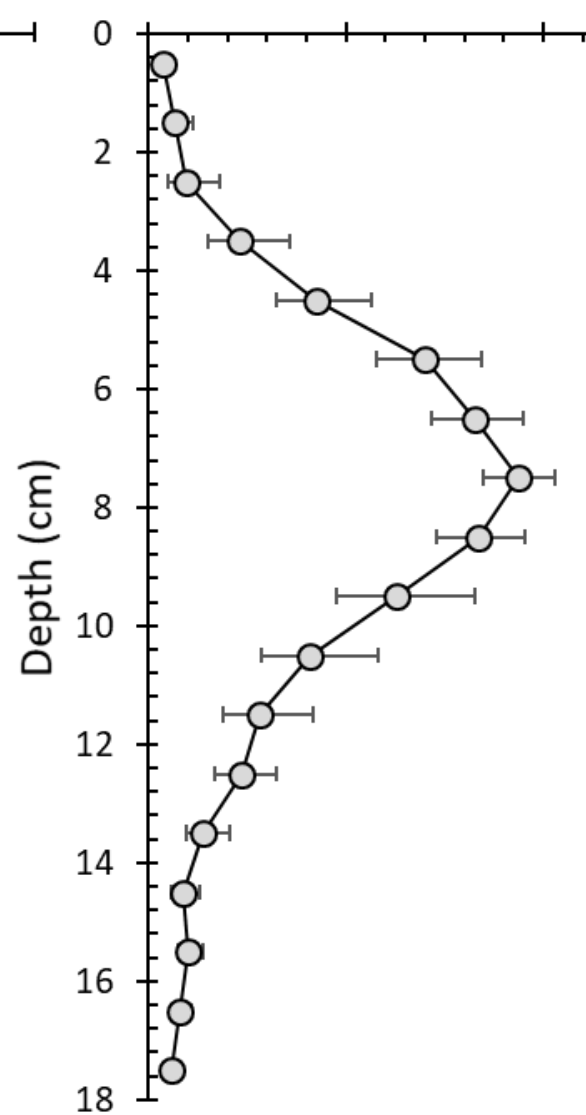

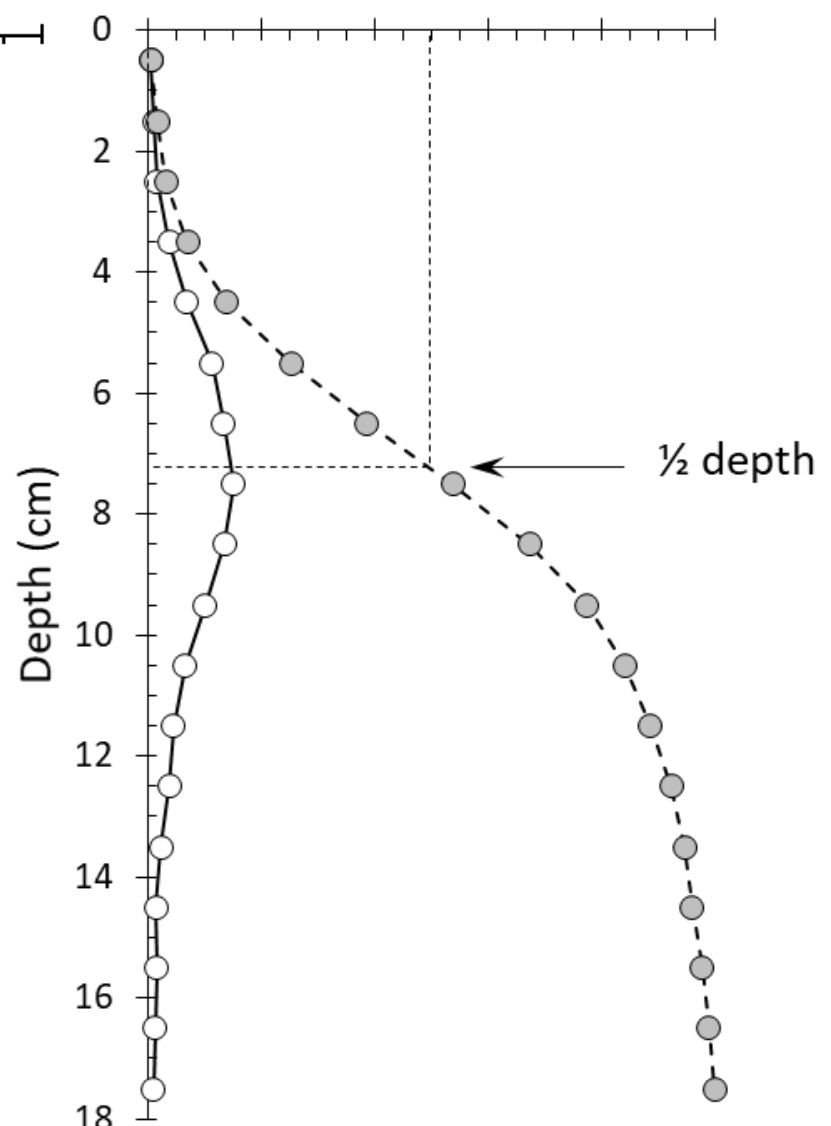

Figure 3: Depth profiles of (a) activity concentration ( $\mathrm{Bq} \mathrm{kg}^{-1}$ ), (b) activity inventory ( $\mathrm{Bq} \mathrm{\textrm {m } ^ { - 2 }}$ ) and (c) percentage and cumulative percentage inventory for ${ }^{137}$ Cs at Boundary Plantation in 2014/15. Points are geometric means; horizontal bars in (a) and (b) are SEM based on inter-sample variation $(n=7)$. Each point represents the mid-point of a $1 \mathrm{~cm}$ soil layer. 

(a)
(b)
(c)
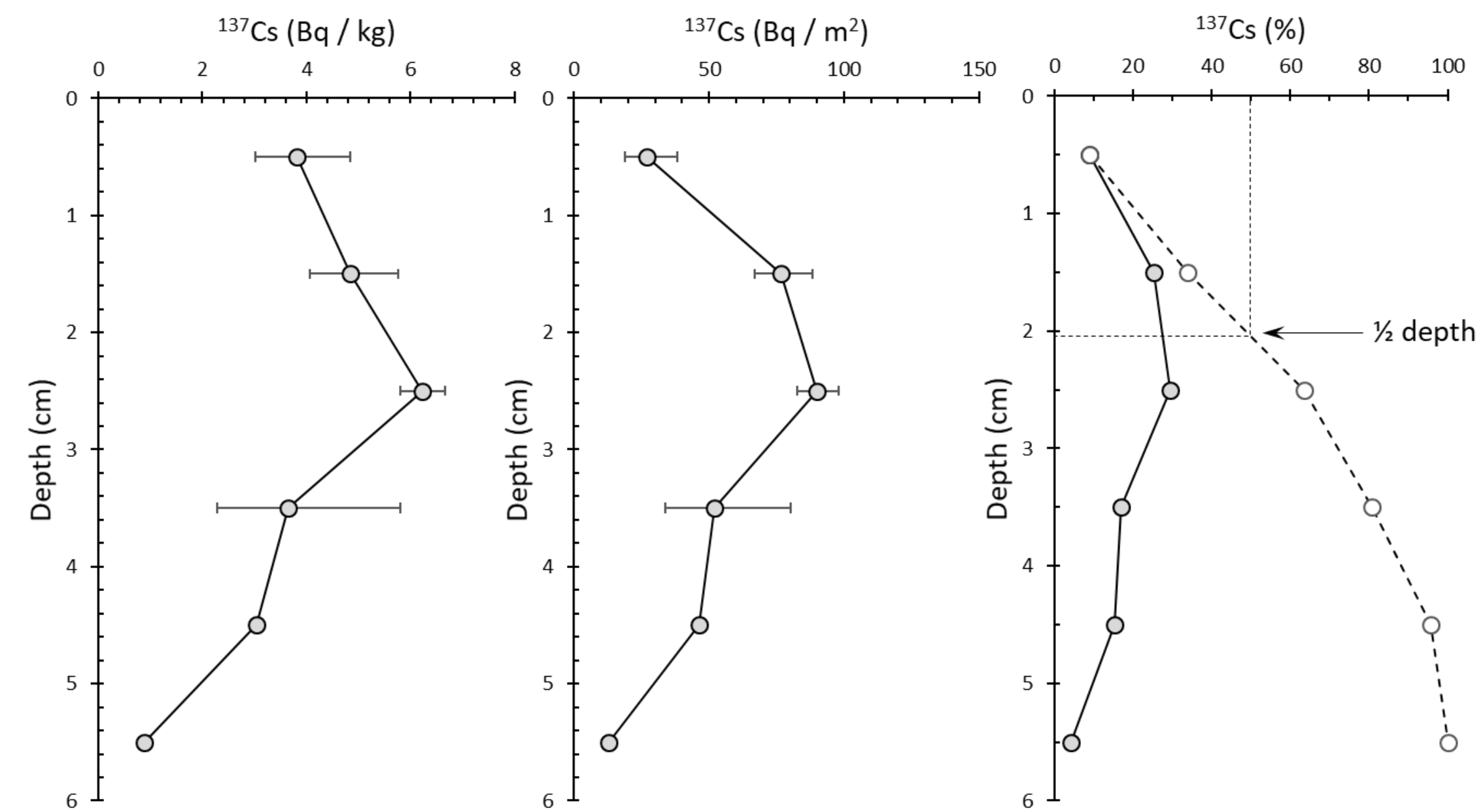

Figure 4: Depth profiles of (a) activity concentration ( $\left.\mathrm{Bq} \mathrm{kg}^{-1}\right)$, (b) activity inventory ( $\mathrm{Bq} \mathrm{m}{ }^{-2}$ ) and (c) percentage and cumulative percentage inventory for ${ }^{137} \mathrm{Cs}$ at Wat Ban Chan in 2016. Points are geometric means; horizontal bars in (a) and (b) are SEM based on inter-sample variation $(n=6)$. Each point represents the mid-point of a $1 \mathrm{~cm}$ soil layer. 
(a)

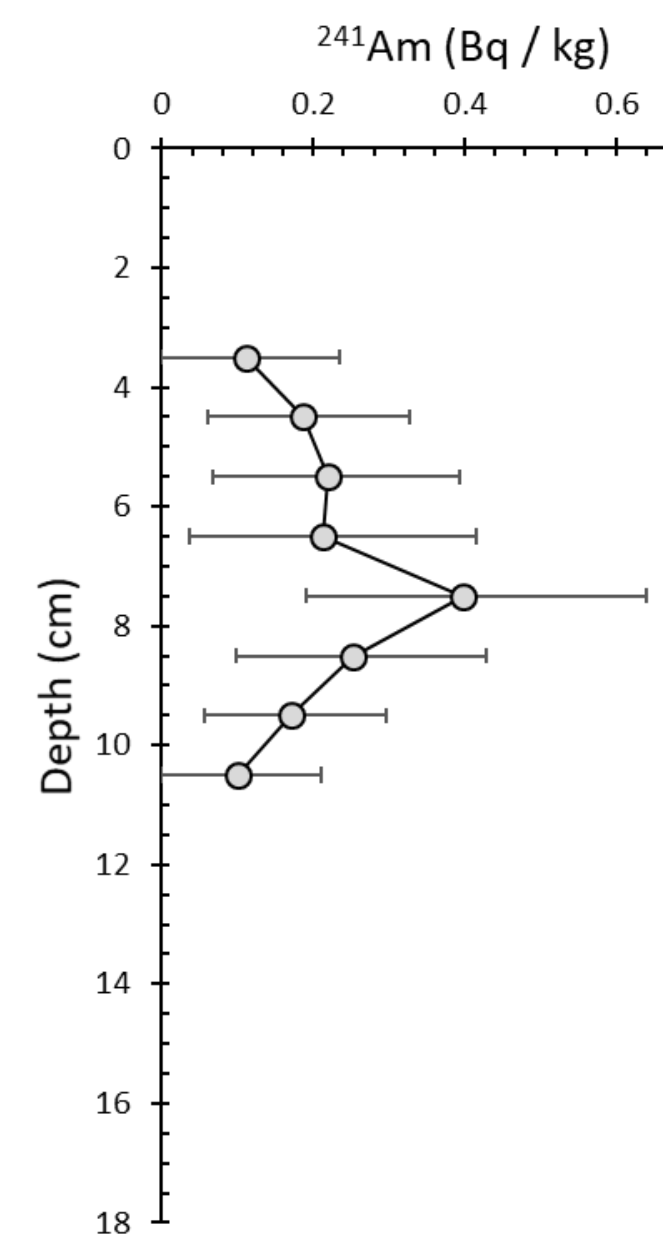

(b)

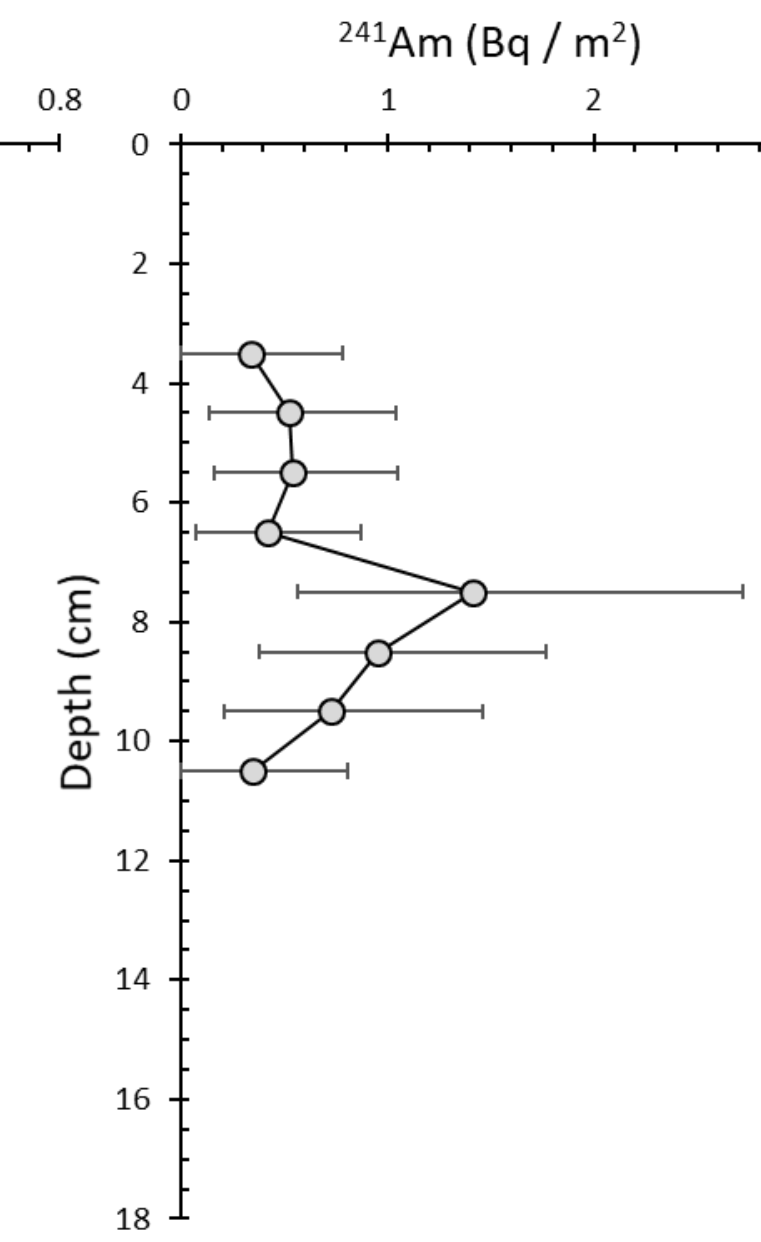

(c)

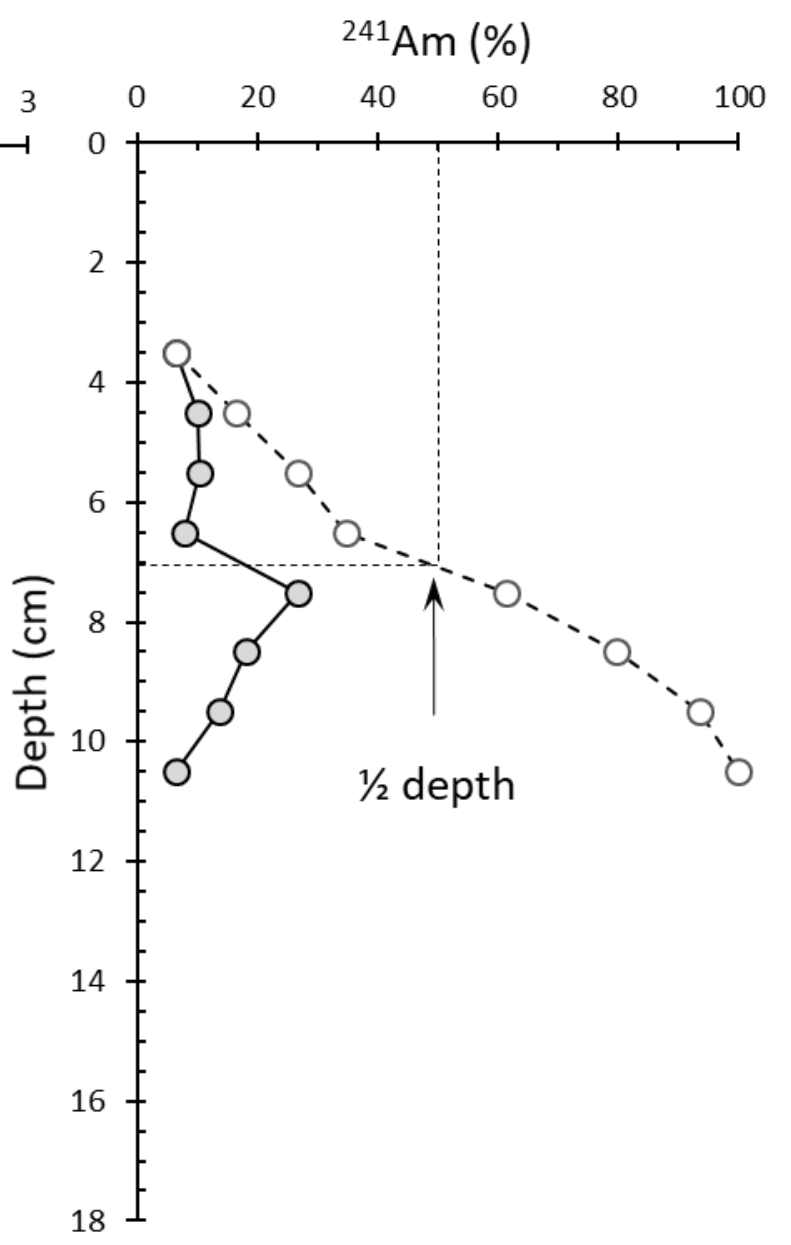

Figure 5: Depth profiles of (a) activity concentration $\left(\mathrm{Bq} \mathrm{kg}^{-1}\right),(\mathrm{b})$ activity inventory $\left(\mathrm{Bq} \mathrm{m}^{-2}\right)$ and (c) percentage and cumulative percentage inventory for ${ }^{241} \mathrm{Am}$ at Boundary Plantation in 2014/15. Points are geometric means; horizontal bars in (a) and (b) are SEM based on intersample variation $(n=7)$. Each point represents the mid-point of a $1 \mathrm{~cm}$ soil layer. 
(a)

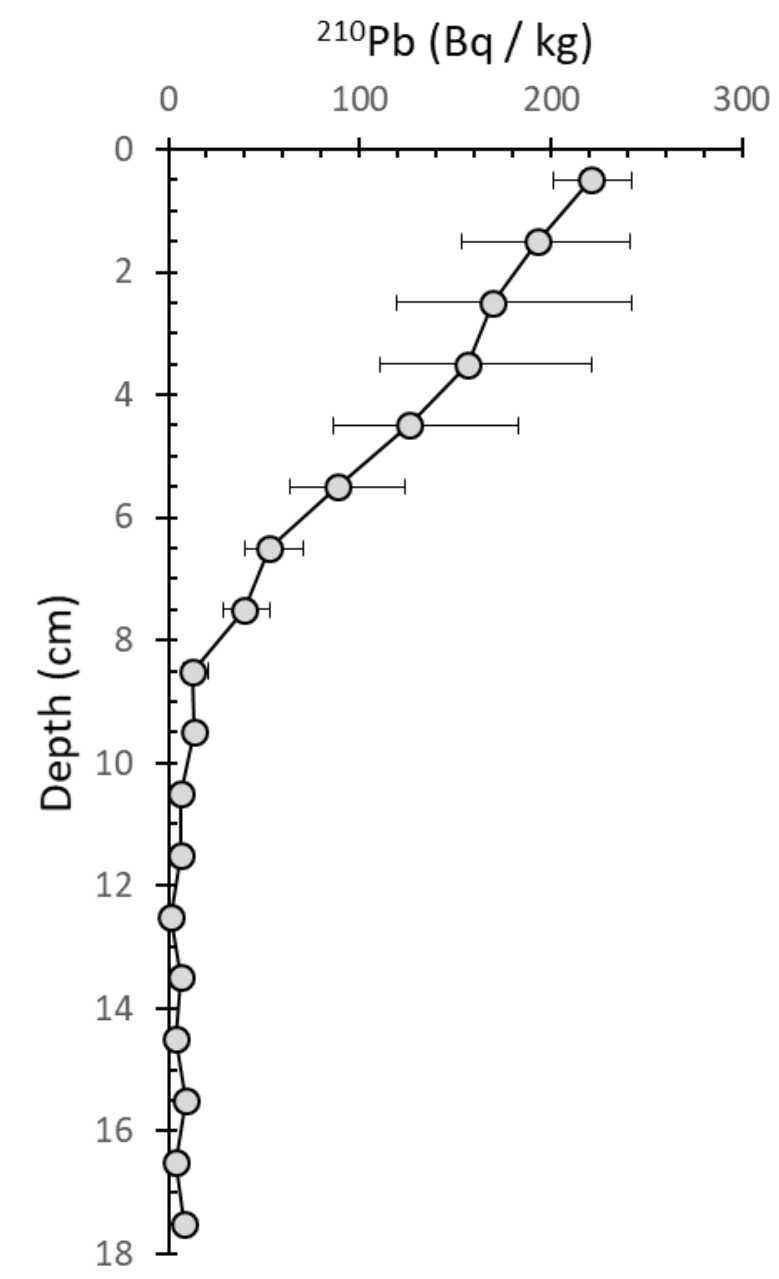

(b)

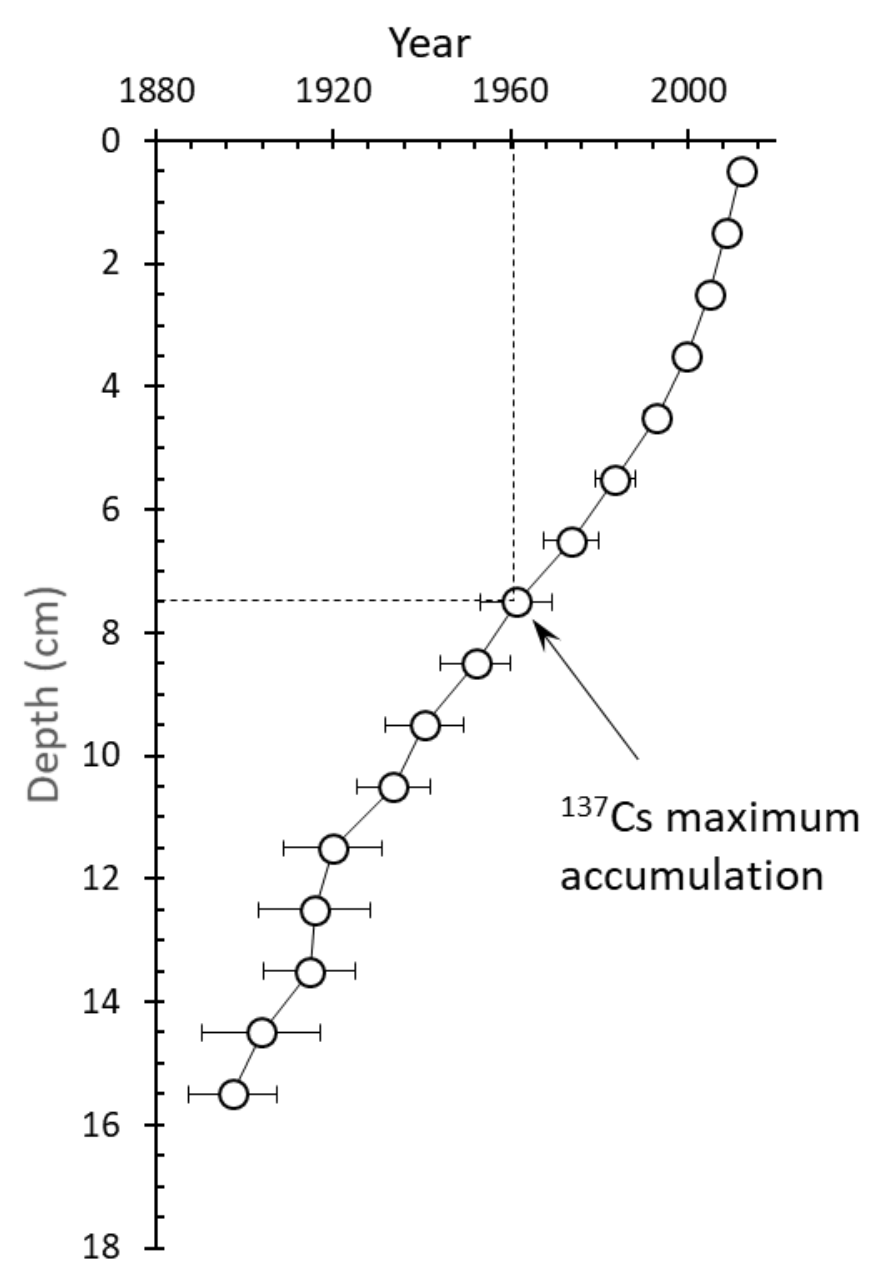

Figure 6: (a) Depth profile of ${ }^{210} \mathrm{~Pb}$ ex activity concentrations at Boundary Plantation and (b) estimates of the year versus soil depth based on the ${ }^{210} \mathrm{~Pb}$ ex activity concentrations. Points are geometric means; horizontal bars are SEM based on inter-sample variation ( $\left.n=7\right)$. Each point represents the mid-point of a $1 \mathrm{~cm}$ soil layer. 
(a)

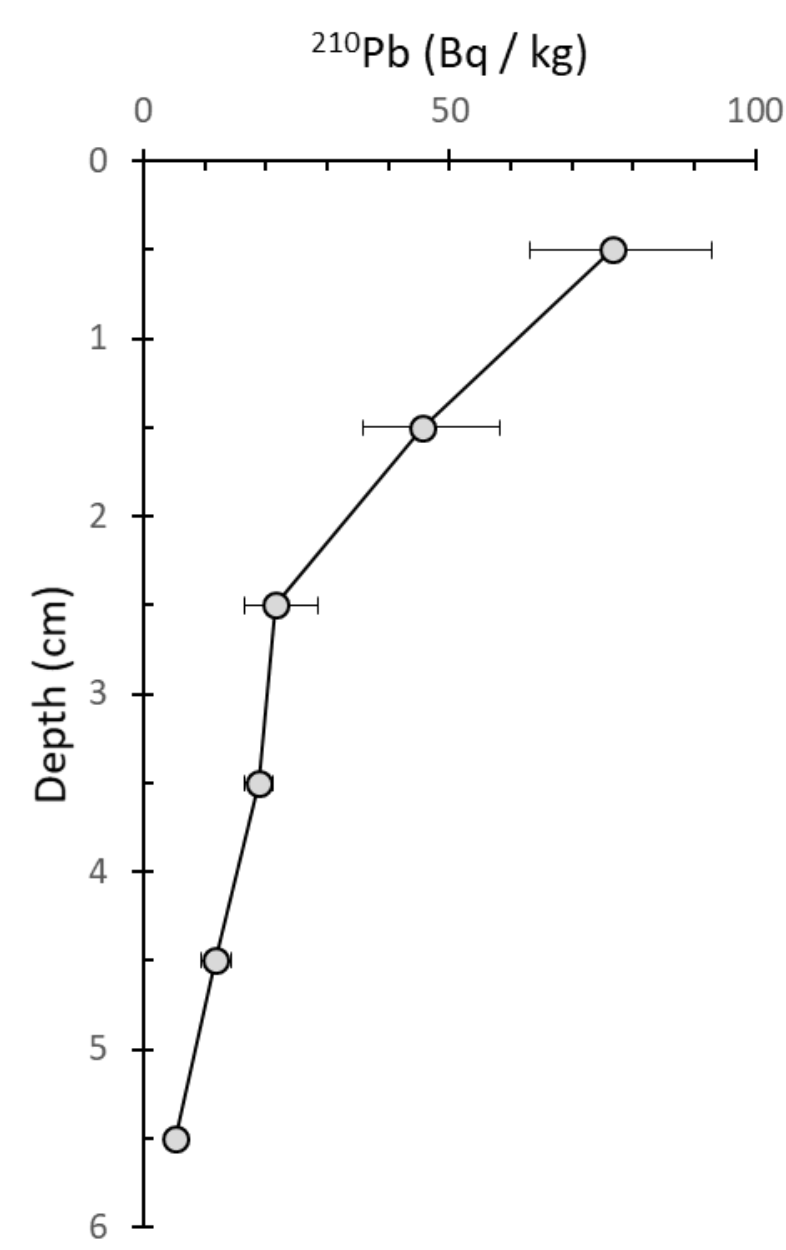

(b)

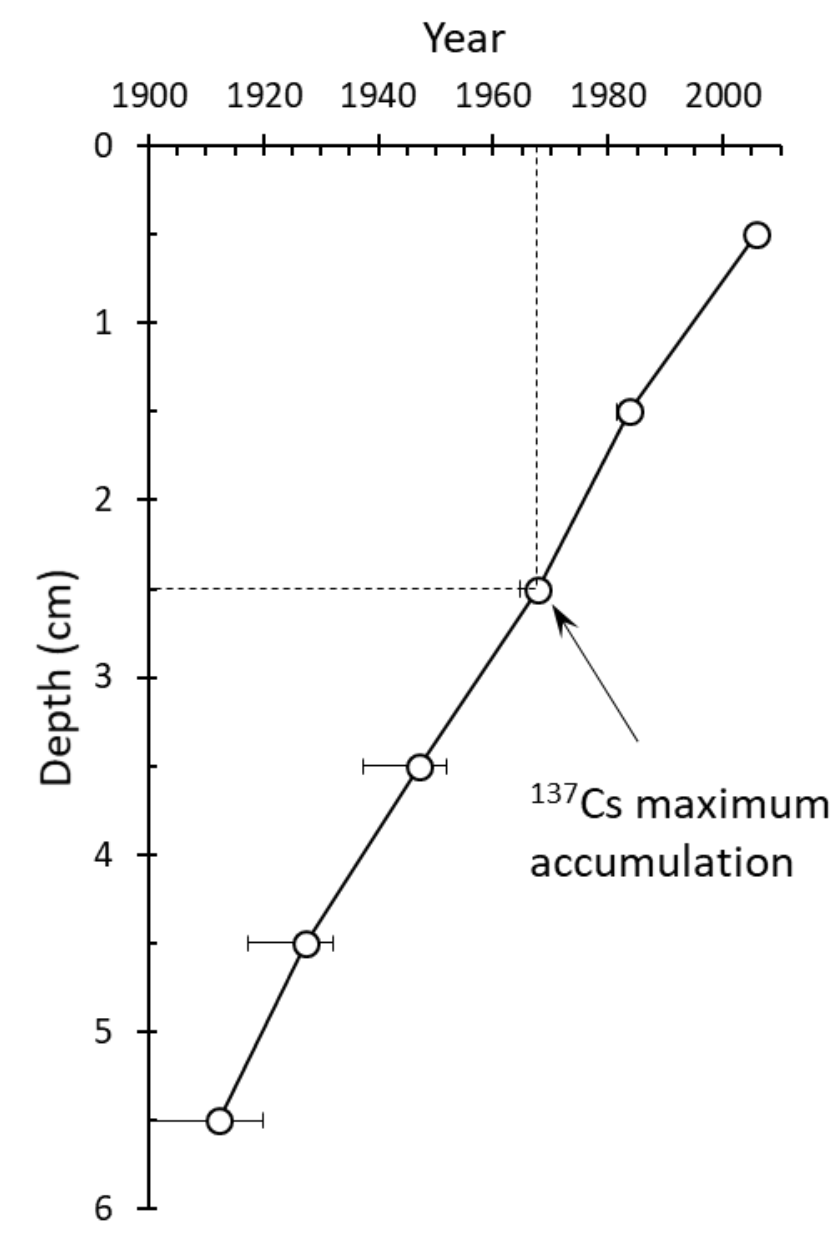

Figure 7: (a) Depth profile of ${ }^{210} \mathrm{~Pb}_{\mathrm{ex}}$ activity concentrations at Wat Ban Chan and (b) estimates of the year versus soil depth based on the ${ }^{210} \mathrm{~Pb}$ ex activity concentrations. Points are geometric means; horizontal bars are SEM based on inter-sample variation ( $\left.n=6\right)$. Each point represents the mid-point of a $1 \mathrm{~cm}$ soil layer. 
Supplementary material for on-line publication only
Click here to download Supplementary material for on-line publication only: Supplementary Figures 07Jan19.docx

Supplementary material for on-line publication only
Click here to download Supplementary material for on-line publication only: Supplementary Figures 07Jan19.docx

(2)

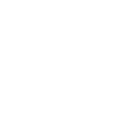

